\title{
Medicaid for All? State-Level Single-Payer Health Care
}

\author{
LINDSAY F. WILEY* \\ TABLE OF CONTENTS
}

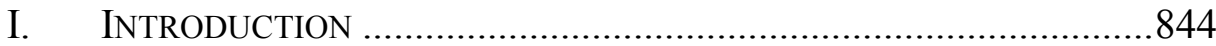

II. MaXimizing Medicaid COVERAGe Under Existing Federal

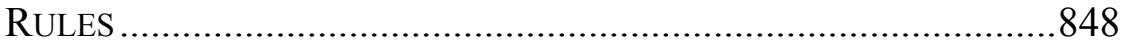

A. Expanding Eligibility Through Optional Statutory Categories

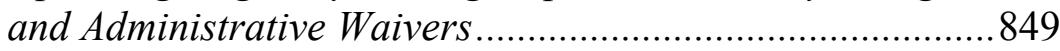

B. Managing Medicaid Managed Care .....................................850

C. Implementing the ACA's Medicaid Expansion .......................852

III. STRIVING FOR FRAGMENTARY BUT UNIVERSAL COVERAGE .........855

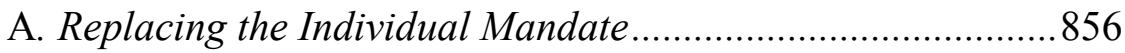

B. Replacing the Employer Mandate .........................................857

C. Restricting Risk-Based Underwriting in the Direct-Purchase

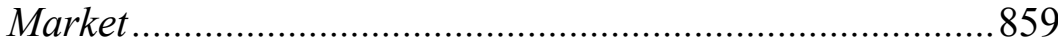

D. Promoting Access to Affordable Direct-Purchase Insurance

E. Allowing Residents to Buy into a Public Option ....................864

1. Complying with Federal Medicaid Law ...........................867

2. Applying ACA Premium Assistance Tax Credits Toward the

Purchase of a Public Option......................................... 870

IV. Going Further: State-LeVel Single-Payer Health CARE .872

A. Repurposing Existing Federal Funds to Finance a State-Level

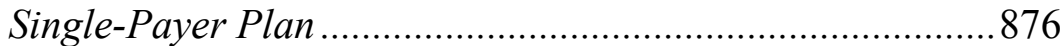

1. Complying with Federal Medicaid Law ..........................877

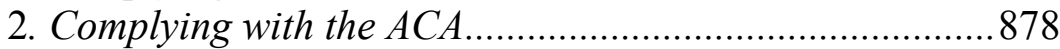

3. Exploring Options Under Medicare .................................879

B. Developing New State Revenues .........................................88

1. Navigating ERISA Preemption ........................................8 881

2. Managing Federal Tax Implications ...............................884

C. Navigating Federal Constitutional Constraints ..................... 885

V. Assessing State Options from a Health Justice Perspective

* Lindsay F. Wiley is a Professor of Law and Director of the Health Law and Policy Program at American University Washington College of Law. The author wishes to thank Wendy Acquazinno and Jacob Peeples for their excellent research assistance, Ryan Steyer for his careful editing and suggestion of additional citations, and the participants in the Ohio State Law Journal Symposium Re-Thinking State Relevance and the Medicaid Matters panel at the 2018 Health Law Professors Conference for their suggestions. 
A. Combatting Stigma and Reducing Political Vulnerability.....888

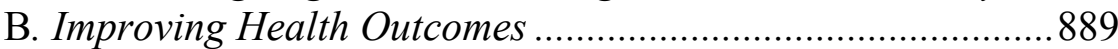

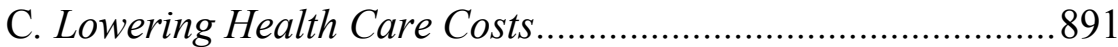

D. Proceeding with a Cautious Eye Toward the Disadvantages of

State-Level Single-Payer Health Care ....................................84

1. Exacerbating Nonfinancial Barriers to Care ....................894

2. Exacerbating Geographic Disparities in Health ...............895

3. Continuing Fragmentary Federal Protections for State-

Level Single-Payer Enrollees...........................................86

4. Putting Federal Protections for the Highest-Need

Populations at Risk

VI. CONCLUSION

\section{INTRODUCTION}

With respect to health, the United States is an outlier. U.S. health care expenditures per capita have consistently been are the highest in the world, exceeding those of the second-highest spender by more than $30 \% .{ }^{1}$ Economists attribute this gap to rapid growth in U.S. spending during the $1980 \mathrm{~s},{ }^{2}$ when public programs and private insurers continued to reimburse hospitals, doctors, and other health care providers on a fee-for-service basis, unconstrained by the kinds of price and spending limits that other countries adopted in response to increasing demands for resources. ${ }^{3}$ In spite of spending about twice as much on health care as other similarly situated countries, ${ }^{4}$ the United States experiences below-average health outcomes by most measures. ${ }^{5}$ We have not kept pace with

\footnotetext{
${ }^{1}$ Bradley Sawyer \& Cynthia Cox, How Does Health Spending in the U.S. Compare to Other Countries?, PETERSON-KAISER HEALTH SYS. TRACKER (Feb. 13, 2018), https://www.healthsystemtracker.org/chart-collection/health-spending-u-s-compare-count ries/\#item-u-s-similar-public-spending-private-sector-spending-triple-comparable-countries [https://perma.cc/3H65-T95N] ("Health spending per person in the U.S. was $\$ 10,348-34 \%$ higher than Switzerland, the next highest per capita spender."); Irene Papanicolas et al., Health Care Spending in the United States and Other High-Income Countries, 319 JAMA 1024, 1026 (2018).

${ }^{2}$ Sawyer \& Cox, supra note 1.

${ }^{3}$ See Papanicolas et al., supra note 1, at 1034; Austin Frakt, Medical Mystery: Something Happened to U.S. Health Spending After 1980, N.Y. TIMES (May 14, 2018), https://www.nytimes.com/2018/05/14/upshot/medical-mystery-health-spending-1980.html [on file with Ohio State Law Journal] (citing David M. Cutler, Equality, Efficiency, and Market Fundamentals: The Dynamics of International Medical-Care Reform, 40 J. ECON. Literature 881 (2002)); Gerard F. Anderson et al., It's the Prices, Stupid: Why the United States Is So Different from Other Countries, 22 HeAlTH AfF. 89, 102 (2003).

${ }^{4}$ Papanicolas et al., supra note 1, at 1027.

${ }^{5}$ See Bradley Sawyer \& Selena Gonzales, How Does the Quality of the U.S. Healthcare System Compare to Other Countries?, PETERSON-KAISER HEALTH SYS. TRACKER (May 22, 2017), https://www.healthsystemtracker.org/chart-collection/quality-u-s-health
} 
the life expectancy gains seen in similarly wealthy countries, a gap some experts attribute to high spending on health care relative to other social programs (such as early childhood education, housing and nutrition assistance, and income support) that play a greater role in determining health outcomes. ${ }^{6}$

At about the same time that medicine began to offer interventions that made a meaningful difference in health outcomes, the costs of illness and the risk of high medical expenses became too great for all but the wealthiest families to bear. ${ }^{7}$ In other countries, the solution was collective financing-either through taxing and spending to support a publicly financed single-payer system or mandatory participation in private insurance funds that cross-subsidize each other to spread risk and process claims via a unified (also known as single pipe) system. ${ }^{8}$ Single-payer and single-pipe systems embody collective action to secure health care access as a public good. In the United States, however, a free market approach prevailed. ${ }^{9}$ Health care providers organized themselves into prepaid Blue Cross and Blue Shield plans purchased directly by individuals and families $^{10}$ and by employers who had begun to offer comprehensive health coverage to workers. ${ }^{11}$ Commercial insurance companies also entered the market. ${ }^{12}$ Private health insurance was heavily subsidized for most U.S. residents, albeit indirectly, via tax laws that exempted health care benefits from payroll and income taxes. ${ }^{13}$ This tax subsidy remains largely hidden from view and insulated from the political attacks leveled against more direct government financing. ${ }^{14}$ Moreover, the exemption of health benefits from taxable income

care-system-compare-countries/?_sft_category=quality-of-care\#item-start [https://perma.cc/XGM6-NPAW].

${ }^{6}$ Frakt, supra note 3 (citing Peter A. Muennig \& Sherry Al. Glied, What Changes in Survival Rates Tell Us About U.S. Health Care, 29 HeAlth AfF. 2105 (2010)); Andrew Fenelon et al., Major Causes of Injury Death and the Life Expectancy Gap Between the United States and Other High-Income Countries, 315 JAMA 609, 609-10 (2016); JENNIFER Rubin et al., Rand CORP., ARe Better Health Outcomes Related to Social EXPENDITURE? A CROSS-NATIONAL EMPIRICAL ANALYSIS OF SOCIAL EXPENDITURE AND POPULATION HEALTH MEASURES 42 (2016), https://www.rand.org/pubs/research_reports/

RR1252.html [https://perma.cc/B3FJ-J4AY].

${ }^{7}$ See Paul Starr, The Social Transformation of American Medicine 236 (1982).

${ }^{8}$ See id. at 237-40; Timothy Stoltzfus Jost, Why Can't We Do What They Do? National Health Reform Abroad, 32 J.L. MED. \& ETHICS 433, 433-35 (2004); WILLIAM C. Hsiao et al., ACt 128 Health System Reform Design: Achieving AfFordable UNIVERSAL HEALTH CARE IN VERMONT 35, 170 (2011).

${ }^{9}$ See STARR, supra note 7, at 240-42 (describing the failure of social insurance and rise of private commercial insurance in the United States).

${ }^{10} I d$. at $294-98$.

${ }^{11}$ Id. at $310-15$.

${ }^{12}$ Id. at $327-31$.

13 Timothy Stoltzfus Jost, Disentitlement?: The Threats Facing Our Public HEALTh-CARE Programs AND A Rights-BASEd Response 78-80 (2003).

${ }^{14}$ Nicole Huberfeld \& Jessica L. Roberts, Health Care and the Myth of Self-Reliance, 57 B.C.L. REV. 1, 16-17, 21 (2016). 
disproportionately benefits higher income households, exacerbating economic health disparities. ${ }^{15}$

Three main groups were left out of this market-driven private insurance system - people of retirement age, people with disabilities, and people living in low-income households. ${ }^{16}$ In 1965, the federal government created Medicare and Medicaid ${ }^{17}$ to soak up risks that the private insurance market could not bear. ${ }^{18}$ Eligibility was limited, and government administrators took a largely hands-off approach to prices and utilization, eschewing the negotiating power publicly financed programs elsewhere in the world exert to check provider demands for higher prices. ${ }^{19}$ The fragmentary mix of publicly and privately financed coverage also allows private insurers to reap substantial profits while requiring health care providers to navigate the requirements of multiple payers, resulting in much higher administrative costs in the United States. ${ }^{20}$

Federal initiatives under the Affordable Care Act of 2012 (ACA) ${ }^{21}$ and the Medicare Access and CHIP Reauthorization Act of 2015 (MACRA) ${ }^{22}$ are chipping away at the margins of our dysfunctional health care system. The ACA expands eligibility for publicly financed coverage under Medicaid, subsidizes the cost of directly purchased private insurance through premium assistance tax credits, strengthens cross-subsidies in the direct-purchase insurance market, and adopts various reimbursement reforms (expanded by MACRA) that reward providers for better outcomes.

Most other countries in the world have made commitments to respect, protect, and fulfill the health-related needs of their populations through international human rights instruments and national constitutional provisions. ${ }^{23}$ In the United States, health care remains first and foremost an economic good financed through a fragmentary system of publicly financed plans, public subsidies for the purchase of private coverage, and private coverage provided as a benefit of employment. ${ }^{24}$ Access to comprehensive clinical care and good health outcomes are among the prizes for doing well financially. ${ }^{25}$ Private

$15 \mathrm{Id}$. at 21.

16 Jost, supra note 13 , at 85-86.

${ }^{17}$ See Social Security Amendments of 1965, Pub. L. No. 89-97, 79 Stat. 286 (1965); JosT, supra note 13 , at $85-86$.

${ }^{18}$ See Jost, supra note 13 , at 85-86.

${ }^{19}$ See generally Anderson et al., supra note 3.

${ }^{20}$ Papanicolas et al., supra note 1, at 1025, 1030; Frakt, supra note 3.

21 The Affordable Care Act consists of both the Patient Protection and Affordable Care Act, Pub. L. No. 111-148, 124 Stat. 119 (2010), and the Health Care and Education Reconciliation Act of 2010, Pub. L. No. 111-152, 124 Stat. 1029.

22 Pub. L. No. 114-10, 129 Stat. 87 (2015).

${ }^{23}$ See generally U.N. CESCR, General Comment No. 14 (2000): The Right to the Highest Attainable Standard of Health (Article 12 of the International Covenant on Economic, Social and Cultural Rights) (Aug. 11, 2000), https://digitallibrary.un.org/record/ 425041/files/E_C.12_2000_4-EN.pdf [https://perma.cc/BG3B-2BZD].

${ }^{24}$ See JosT, supra note 13 , at $78-80$.

${ }^{25}$ See STARR, supra note 7, at 236. 
insurers assert their interest in community prevention, ${ }^{26}$ but because most individuals will transition among various payers over the course of their lives, insurers' incentives are not well aligned with farsighted prevention goals. ${ }^{27}$ Private insurers and employers use the rhetoric of personal responsibility for health and wellness to shift costs to individuals and families. ${ }^{28}$ Health justice, including affordable access to high-quality health care and healthy living conditions for all, is derided as the pie in the sky dream of far-left progressives. ${ }^{29}$

What role can progressive states play in making health justice a reality? At a time when the Trump Administration and the Republican majority in Congress are undermining the fragile gains of the ACA through partial repeal and litigation while simultaneously attacking older federal commitments embodied in the Medicaid program, ${ }^{30}$ state governments are facing tough choices. This article describes three basic strategies states are exploring for achieving universal access to high-quality health care and better health outcomes for their residents. First, maximizing eligibility for Medicaid using matching federal funds. Second, taking up the mantle of Obamacare by adopting state-level replacements for provisions that federal lawmakers repeal, subsidizing and regulating the price of private insurance, and making more affordable coverage available for purchase on state-run health insurance exchanges. Third, I focus particularly on the efforts of states to succeed where federal reformers have failed by adopting a state-level public option or single-payer health care system. Although state-level public-option and single-payer health plans face significant obstacles, many believe they are more feasible than federal reforms. Moreover, I argue, state-level single-payer health care may be preferable from a health justice perspective because it holds greater promise for integrating health care, public health, and social safety net program goals to achieve better health for all. State lawmakers must proceed cautiously, however, particularly with respect to ensuring that people entitled to traditional Medicaid benefits, which offer special coverage for special populations, continue to receive them. Additionally, state lawmakers should carefully assess the role that privatized public coverage

${ }^{26}$ See Jessica Mantel, Tackling the Social Determinants of Health: A Central Role for Providers, 33 GA. St. U.L. REV. 217, 274, 280 (2017).

${ }^{27}$ Lindsay F. Wiley, Access to Health Care as an Incentive for Healthy Behavior? An Assessment of the Affordable Care Act's Personal Responsibility for Wellness Reforms, 11 IND. HEALTH L. REV. 635, 640 (2014).

${ }^{28} I d$. at 639.

${ }^{29}$ See Lindsay F. Wiley, From Patient Rights to Health Justice: Securing the Public's Interest in Affordable, High-Quality Health Care, 37 CARDOzo L. REV. 833, 874 (2016) [hereinafter Wiley, Patient Rights].

${ }^{30}$ See Graham-Cassidy-Heller-Johnson Amendment, H.R. 1628, 115th Cong. (2017); see also KAISER FAM. Found., Summary of Graham-Cassidy-Heller-Johnson Amendment (Sept. 2017), http://files.kff.org/attachment/Summary-of-Graham-Cassidy-Heller-JohnsonAmendment [https://perma.cc/BXY2-3NFA] (stating that, among other things, the Amendment seeks to "[r]epeal ACA mandates and premium and cost sharing subsidies," limit growth in federal Medicaid spending, "[a]dd a state option to require work as a condition of Medicaid eligibility," and "[r]epeal several ACA revenue provisions"). 
currently plays in their health systems and what role, if any, it should play in public-option or single-payer reforms.

I begin in Part I by describing the legal framework that governs state options for maximizing Medicaid eligibility with matching federal funds while managing the longstanding trend toward Medicaid privatization. In Part II, I discuss state options for strengthening implementation of the fragmentary but universal coverage approach adopted in the ACA, including by offering a statelevel public option. In Part III, I turn to single-payer proposals. Finally, in Part IV, I assess state health-reform options from a health justice perspective, arguing that state-level single-payer financing has many advantages over the alternatives. Throughout this Article, I identify and offer a preliminary assessment of several open questions of law, particularly with respect to federal preemption of state authority to regulate employer-based insurance under the Employee Retirement Income Security Act (ERISA) ${ }^{31}$ and the necessity and availability of administrative waivers under Medicaid, Medicare, and the ACA. My goal is not to resolve every one of these issues in a single article. Rather, my aim is to map the issues and argue that health law and policy scholars should continue to study them in detail given the benefits that could flow from pursuing a more radical health reform agenda at the state level.

\section{MaXimizing MedicAid Coverage Under EXISTING FederaL RULES}

Medicaid provides publicly financed coverage for people living in lowincome households who meet additional eligibility requirements. ${ }^{32}$ Together with the Children's Health Insurance Program ${ }^{33}$ (which provides additional federal funding to states with fewer strings attached), Medicaid currently covers nearly 74 million Americans, most of whom are children. ${ }^{34}$ It is jointly financed by the federal government and the states..$^{35}$ Each state must make important

3129 U.S.C. $\S \S 1001-1461$ (2012).

32 Elicia J. Herz et AL., Cong. ReSearch Serv., RL32277, How Medicaid Works: PRogram BASICS 1-2 (2006).

33 See Balanced Budget Act of 1997, Pub. L. No. 105-33, 111 Stat. 251 (1997); Medicare Access and CHIP Reauthorization Act of 2015, Pub. L. No. 114-10, 129 Stat. 87 (2015).

${ }^{34}$ May 2018 Medicaid \& CHIP Enrollment Data Highlights, MEDICAID.GOv, https://www.medicaid.gov/medicaid/program-information/medicaid-and-chip-enrollmentdata/report-highlights/index.html [https://perma.cc/YPD4-SQZ4].

${ }^{35}$ For 2016, the federal share of Medicaid costs was about $63 \%$ overall, varying from nearly $80 \%$ in Kentucky to about $50 \%$ in Virginia. See Federal and State Share of Medicaid Spending, KAISER FAM. FOUND., https://www.kff.org/medicaid/state-indicator/federalstateshare-of-spending/ [https://perma.cc/Z22V-US4J]. Each state's Federal Medical Assistance Percentage (FMAP), determined by the state's average income, applies to most Medicaid spending. Certain benefits (e.g., family planning) and recipients (e.g., Native Americans, ACA newly eligibles) are covered by higher match rates. See Federal Medical Assistance Percentage (FMAP) for Medicaid and Multiplier, KAISER FAM. FOUND., 
choices about who is eligible, which goods and services are covered, and how providers are paid. States may pursue their health reform goals by taking advantage of statutory flexibility, administrative waivers, and contracts that incentivize health care providers to control costs.

\section{A. Expanding Eligibility Through Optional Statutory Categories and Administrative Waivers}

Medicaid eligibility is determined by a mix of categories that states must cover as a condition of participation in the program (mandatory categories) and additional categories that a state may cover with matching federal funds if it wishes to do so (optional categories). ${ }^{36}$ For example, states must cover pregnant women living in households with incomes at or below $133 \%$ of the federal poverty level (FPL). ${ }^{37}$ They have the option, however, to cover pregnant women up to $185 \%$ of FPL with the help of matching federal funds. ${ }^{38}$ Similarly, states must cover all children under the age of nineteen up to at least 133\% of FPL, ${ }^{39}$ but states have several options for expanding coverage using optional categories. ${ }^{40}$

States wishing to cover people or services outside of these statutory categories must do so without federal assistance unless they receive a waiver from the Secretary of Health and Human Services (HHS). ${ }^{41}$ Section 1115 of the Social Security Act gives the HHS Secretary authority to waive the requirements of Section $1902^{42}$ of the Medicaid statute on a case-by-case basis as part of an

https://www.kff.org/medicaid/state-indicator/federal-matching-rate-and-multiplier/ [https://perma.cc/2RWU-B4SR].

36 See MEDICAID AND CHIP PAYMENT AND ACCESS COMMISSION (MACPAC), Mandatory AND Optional EnRollees AND SeRVices in Medicaid 1, 5 (June 2017), https://www.macpac.gov/wp-content/uploads/2017/06/Mandatory-and-Optional-Enrolleesand-Services-in-Medicaid.pdf [https://perma.cc/74CX-DYVJ][hereinafter MACPAC].

${ }^{37}$ See Social Security Act, 42 U.S.C. $\S \S 1396 a(a)(10)(A)(i)(I I I),(I V)$ (2012); id. $\S 1396 \mathrm{a}(\mathrm{l})(1)(\mathrm{A})$; id. $\S 1396 \mathrm{~d}(\mathrm{n})$; see also 42 C.F.R. $\S 435.116$ (2014). Some states have higher mandatory eligibility levels for infants and pregnant women, ranging from $150 \%$ to $185 \%$ FPL, due to the fact that they had already expanded to these levels when legislation was enacted in 1989 to mandate coverage of pregnant women up to at least 133\% FPL. Omnibus Budget Reconciliation Act of 1989, Pub. L. No. 101-239, 103 Stat. 2106, 2258 (1989). States are required to maintain these higher preexisting thresholds. 42 U.S.C. $\S 1396 \mathrm{a}(\mathrm{a})(10)(\mathrm{A})(\mathrm{iii})$.

38 See 42 U.S.C. $\S 1396 \mathrm{a}(\mathrm{a})(10)(\mathrm{A})(\mathrm{ii})(\mathrm{I}),(\mathrm{IV}),(\mathrm{IX}) ;$ id $\S 1396 \mathrm{a}(\mathrm{l})(2) ; 42$ C.F.R. $\S 435.116(\mathrm{c})(1)(\mathrm{ii})(2014)$.

${ }^{39}$ See 42 U.S.C. § 1396a(a)(10)(A)(i)(I), (III), (VI), (VII); id. §§ 1396a(l)(1)(C), (D); id. $\S 1396 \mathrm{~d}(\mathrm{n}) ; 42$ C.F.R. $\S 435.118$ (2013) (mandating that children between ages one and eighteen be covered, and allowing states to establish different income standards for age brackets within that range).

${ }^{40}$ See 42 U.S.C. § 1396a(a)(10)(A)(ii)(I), (IV), (IX); id. § 1396a(l)(2).

${ }^{41}$ See generally id. § 1396 a.

${ }^{42}$ See generally id. 
experimental, pilot or demonstration project. ${ }^{43}$ By statute, the Secretary must determine that the state's proposal "is likely to assist in promoting the objectives of [the Medicaid Act]." "44 Pursuant to longstanding HHS policy, the state's plan should also be budget neutral, meaning that it should not increase federal costs above the level anticipated in the absence of a waiver. ${ }^{45}$ Eligibility expansion waivers, unlike requests to impose harsher requirements or cut benefits, easily satisfy these requirements. ${ }^{46}$ But the state must carefully negotiate with HHS Centers for Medicare and Medicaid Services (CMS) over the baseline federal commitment for determining budget neutrality. ${ }^{47}$ Moreover, the HHS Secretary has wide latitude to deny a state's application even if the statutory requirements are met. ${ }^{48}$ To pursue such a waiver, the state must enact authorizing legislation and provide opportunities for public comment. ${ }^{49}$

\section{B. Managing Medicaid Managed Care}

Eligibility expansions via statute and waiver have often come hand-in-hand with the rise of managed care and privatization. When people think of Medicaid, they tend to envision a government agency paying health care providers for the goods and services they provide to enrollees. That vision is outdated. Most Medicaid recipients are enrolled in managed care plans, which reduce costs by contracting with restricted networks of providers who agree to bear some of the financial risk that enrollees will require more expensive care than anticipated and share the savings if they require less. ${ }^{50}$ Additional financial incentivesamounting to $3 \%-5 \%$ of payments in Vermont, for example - are tied to specified quality indicators. ${ }^{51}$ States typically pay a negotiated fee per enrollee, adjusted based on health-related risk factors (capitated payment) to one or more private insurance companies who, in turn, share their financial risk with health care providers, giving them incentives to steward limited health care resources carefully. ${ }^{52}$ Vermont, however, has developed a unique approach whereby a

${ }^{43} I d . \S 1315(\mathrm{a})$.

${ }^{44} \mathrm{Id}$.

${ }^{45}$ Laura D. Hermer, On the Expansion of "Welfare" and "Health" Under Medicaid, 9 St. Louis U.J. HEALTH L. \& POL'Y 235, 237 \& n.11 (2016).

${ }^{46}$ See Abbe R. Gluck \& Nicole Huberfeld, The New Health Care Federalism on the Ground, 15 InD. HeALTH L. REV. 1, 9 (2018).

${ }^{47}$ See id. at $9-10$.

48 See Id.

4942 U.S.C. $\S 1315(\mathrm{~d})$.

50 Isaac D. Buck, Managing Medicaid, 11 St. Louis U.J. HeAlth L. \& POL'Y 107, 117 20 (2017).

${ }^{51}$ Rob Houston \& Jim Lloyd, Vermont's Next Generation ACO Program Breaks New Ground in Medicaid, CTR. FOR HeAlth CARE StRATEgies (May 10, 2016), https://www.chcs.org/vermont-next-generation-aco-program-breaks-new-ground-inmedicaid/ [https://perma.cc/9BQZ-V7ZY].

${ }^{5}$ See Buck, supra note 50 , at $111 \&$ n.9. The number of private insurance companies participating in Medicaid managed care ranges from zero (in the eleven states that have not 
state agency operates the only managed care plan in the state, contracting directly with providers. ${ }^{53}$ The state may fulfill its obligation to ensure compliance with federal requirements solely through commitments it secures from private contractors, which promise to adhere to specified standards in their contracts with providers, quality assurance, reimbursement methodologies, claims adjudication, care management, and other functions. ${ }^{54}$ In other cases (e.g., Vermont), the state retains direct control over these functions. ${ }^{55}$ Most states have adopted a mix of both strategies - purchasing fully privatized basic coverage for many enrollees while retaining direct control over certain services (especially those that tend to be high-cost, such as long-term care) for certain categories of enrollees (e.g., people with disabilities). ${ }^{56}$

The federal government and the states have privatized Medicaid through a combination of administrative waivers and legislative amendments. During the early 1990s, following major eligibility expansions via federal statute, several states obtained waivers to transition at least some enrollees to managed care. ${ }^{57}$ Some relied on managed care savings to expand eligibility to additional populations while maintaining budget neutrality. ${ }^{58}$ In the next wave of waivers, during the early 2000s, several additional states expanded eligibility (while ostensibly ensuring budget neutrality) by enrolling newly eligible recipients in private plans and imposing premiums and copays on enrollees. ${ }^{59}$ The Deficit

yet adopted managed care and in Vermont, where a state agency administers the sole Medicaid managed care plan itself and contracts directly with provider organizations) to twenty-three (in New York); see Total Medicaid MCOs, KAISER FAM. FounD., https://www.kff.org/medicaid/state-indicator/total-medicaid-mcos/ [https://perma.cc/GEL46XKV].

53 See Houston \& Lloyd, supra note 51.

${ }^{54}$ See generally Julia Paradise \& MaryBeth Musumeci, CMS's Final Rule on Medicaid Managed Care: A Summary of Major Provisions, KAISER FAM. Found. (June 2016), https://www.kff.org/medicaid/issue-brief/cmss-final-rule-on-medicaid-managed-care-asummary-of-major-provisions/ [https://perma.cc/ENB3-4Z7V] (summarizing a series of 2016 CMS regulations that "revise[d] and significantly strengthen[ed]" the regulatory framework and requirements around Medicaid managed care programs).

${ }^{55}$ HSIAO ET AL., supra note 8 , at 30.

56 Paradise \& Musumeci, supra note 54; Alice Burns \& Benjamin LAYTon, Cong. Budget Office, Exploring the Growth of Medicaid Managed Care 2-3, 18 (Aug. 2018), https://www.cbo.gov/system/files?file=2018-08/54235-MMC_chartbook.pdf [https://perma.cc/86YC-EZPV].

57 JOST, supra note 13, at 122-24.

58 See Hermer, supra note 45, at 238-39; see also FrAnK J. THOMPSON, MEDICAID Politics: Federalism, Policy DuRABility, AND Health ReForm 140 (2012) (presenting examples of states that linked eligibility expansions to managed care initiatives).

${ }^{59}$ Hermer, supra note 45 , at 238-39. Cost-sharing includes premiums (essentially a user fee for obtaining coverage), deductibles (a predetermined amount that enrollees must pay out of pocket before coverage kicks in), and copayments (a flat fee or proportion of costs that enrollees must pay for specified services). Absent a waiver, federal Medicaid rules sharply limit cost sharing. Id. 
Reduction Act of 2005 (DRA) ${ }^{60}$ allowed states to provide coverage for specified populations via Alternative Benefit Plans (ABPs, also known as benchmark plans). ${ }^{61}$ These plans are exempt from key provisions of the Medicaid statute, including many of the mandatory benefit categories (e.g., long-term care and coordination of care by social workers) ${ }^{62}$ that distinguish traditional Medicaid as special coverage for special populations. ${ }^{63}$ Specified categories of Medicaid enrollees have the right to remain in traditional Medicaid plans. ${ }^{64}$ Among others, people with qualifying disabilities, people for whom Medicaid supplements Medicare coverage, people who are pregnant and living on household incomes up to $133 \%$ FPL, and those who are medically frail may be offered the option of enrolling in a benchmark plan, but may not be required to do so. ${ }^{65}$ Moreover, children, even if they are enrolled in a plan governed by the ABP standards, are entitled to coverage for early periodic screening, diagnosis and testing services (EPSDT) — a bedrock of traditional Medicaid coverage. ${ }^{66}$

\section{Implementing the ACA's Medicaid Expansion}

Prior to implementation of the ACA's Medicaid expansion in 2014, statutory flexibility and administrative waivers had already resulted in wide variation in eligibility rules and the penetration of managed care and privatization from state to state. ${ }^{67}$ Nationwide in 2013 , a little over $70 \%$ of all Medicaid enrollees fell into mandatory eligibility categories while the rest were in optional categories. ${ }^{68}$ In some states, such as Nevada, virtually no Medicaid enrollees were drawn from optional eligibility categories. ${ }^{69}$ On the other end of

${ }^{60}$ Pub. L. No. 109-171, 120 Stat. 4 (2006).

${ }^{61}$ Deficit Reduction Act of 2005, 42 U.S.C. $\S 1396 u-7$ (2012).

${ }^{62}$ Id. $\S 1396 u-8(\mathrm{c})$; State Flexibility for Medicaid Benefit Packages, 75 Fed. Reg. 23,068, 23,068 (Apr. 30, 2010) (to be codified at 42 C.F.R. pt. 440).

${ }^{63}$ See THOMPSON, supra note 58, at 11 (describing traditional Medicaid benefits as extending "beyond the medical model" to encompass long-term care consisting of "personal assistance - helping enrollees cope with basic tasks of daily living, such as getting dressed and going to the toilet").

6442 C.F.R. $\S 440.315$ (2017).

6542 U.S.C. $\S 1396 u-7(a)(2)(B) ; 42$ C.F.R. $\S 440.315$ (2014).

66 See generally 42 U.S.C. § 1396; 42 C.F.R. § 440.345; see also MaryBeth Musumeci \& Julia Foutz, Medicaid's Role for Children with Special Health Care Needs: A Look at Eligibility, Services, and Spending, KAISER FAM. FOUND. 5 (Feb. 22 2018), https://www.kff.org/medicaid/issue-brief/medicaids-role-for-children-with-special-healthcare-needs-a-look-at-eligibility-services-and-spending/ [https://perma.cc/YD5H-SGKL] ("Medicaid's Early and Periodic Screening Diagnostic and Treatment (EPSDT) benefit includes regular medical, vision, hearing, and dental screenings as well as the services necessary to 'correct or ameliorate' physical or mental health conditions.").

67 See, e.g., MACPAC, supra note 36 , at 13-14.

${ }^{68}$ See $i d$. at $13-14$.

${ }^{69}$ Id. at 3 ("[A]lmost all (95.8\%) enrollees were mandatory in Nevada."). Although the percentage of Medicaid enrollees who fall into optional or waiver-based eligibility categories 
the spectrum, a few jurisdictions stood out as being particularly progressive in their efforts to expand their residents' access to Medicaid, including Vermont (with $65.2 \%$ of enrollees drawn from optional categories), New Hampshire (51.8\%), Hawaii (50.1\%), Massachusetts (48.8\%), and D.C. (47.1\%). ${ }^{70}$ Nationwide, nearly $75 \%$ of enrollees were enrolled in managed care plans, most of which are operated by private companies. ${ }^{71}$ In eight states, (Colorado, Hawaii, Idaho, Missouri, Oregon, Pennsylvania, Tennessee, and Utah), more than $90 \%$ of enrollees were covered by managed care. ${ }^{72}$ In four others, (Alaska, Connecticut, New Hampshire, and Vermont), all enrollees remained in publicly administered coverage. ${ }^{73}$ Notably, the vanguard states pursuing the strategies described in Parts II and III come from both ends of the spectrum with respect to privatization and expansion of eligibility.

The ACA's drafters sought to extend Medicaid to all nonimmigrants living at or below $133 \%$ FPL. ${ }^{74}$ To opt out, a state would have to forgo all of its Medicaid funding. ${ }^{75}$ The Supreme Court's ruling in NFIB v. Sebelius rendered the expansion optional for states, ${ }^{76}$ exacerbating geographic health disparities. In January 2014, when the ACA's eligibility expansion went into effect, twenty-

is determined in part by population characteristics, it does offer a basis for comparing the cumulative effect of state policy choices.

${ }^{70} \mathrm{Id}$. at $39-40$.

${ }^{71}$ Karina Wagnerman et al., Mathematica Policy Research, CTRS. FOR MEDICARE \& Medicaid Services, Medicaid Managed Care Trends and Snapshots 2000-2013 5, https://www.medicaid.gov/medicaid-chip-program-information/by-topics/data-and-systems /medicaid-managed-care/downloads/2013-medicaid-managed-care-trends-and-snapshots2000-2013.pdf [https://perma.cc/4YUV-RWP9].

${ }^{72}$ Id. at 6-7.

${ }^{73} \mathrm{Id}$. Although Vermont is listed as enrolling $56.5 \%$ of Medicaid recipients in managed care, Vermont's sole Medicaid managed care plan is publicly administered. See generally Managed Care in Vermont, MEDICAID.GOv, https://www.medicaid.gov/medicaid-chipprogram-information/by-topics/delivery-systems/managed-care/downloads/vermont-mc p.pdf [https://perma.cc/F5TJ-AC7W] [hereinafter Vermont] ("[Vermont] uses a public managed care model in which the Vermont Agency for Human Services (AHS), the state Medicaid agency, oversees the state's Department of Vermont Health Access (DVHA), which serves as the state's sole managed care organization .... [This] unique 'managed care' model [is] authorized in their [Medicaid Section 1115 waiver program approved by CMS].... Through intergovernmental agreements DVHA 'contracts' with other AHS departments to provide admin and service management functions common to a managed care organization but does not provide any direct clinical services on its own ... [T] he funding flow[s] through DVAH and AHS to providers that receive funding through "value-based payment methodologies' that encourage quality and cost improvements.").

7442 U.S.C. § 1396a(a)(10)(A)(i)(VIII) (2012).

${ }^{75}$ See Nat'l Fed'n of Indep. Bus. v. Sebelius, 567 U.S. 519, 586 (2012) (finding the ACA provision to be "unconstitutional when applied to withdraw existing Medicaid funds from States that decline to comply with the requirements of that Act").

${ }^{76} \mathrm{Id}$. (holding that the mandatory nature of the expansion was impermissibly coercive and thus exceeded the scope of Congress's spending power and relying on the severability provision in the original Medicaid statute to redraft the ACA's Medicaid expansion, rendering it optional). 
six states participated. ${ }^{77}$ As of July 2018, thirty-four states (including the District of Columbia) have adopted the ACA's Medicaid eligibility expansion, and three more states are considering it. ${ }^{78}$ Medicaid expansion has become an important political and legal issue in some states, with all three branches of government — and the people themselves via voter referenda — playing a role. ${ }^{79}$

In keeping with past trends linking eligibility expansions to managed care, the ACA also increased the dominance of privatized Medicaid managed care plans $^{80}$ while subjecting many managed care plans to more stringent regulation. ${ }^{81}$ By statute, the ACA expansion population must be enrolled in alternative benefit plans, even if the state has not previously adopted benchmark coverage for other enrollees. ${ }^{82}$ The ACA and accompanying regulations also imposed somewhat more stringent regulation on benchmark plans, requiring them to offer the same essential health benefits (EHB) package mandated for qualified health plans sold on the state health insurance exchanges. ${ }^{83}$ In a 2016 rule, CMS took pains to align the requirements for Medicaid managed care plans with those applicable to the plans sold on the ACA insurance exchanges (known as Qualified Health Plans) and privatized Medicare plans (also known as Medicare Advantage, Medicare Part C, or Medicare Plus Choice plans). ${ }^{84}$ This

77 See Sarah Miller \& Laura R. Wherry, Health and Access to Care During the First 2 Years of the ACA Medicaid Expansions, 376 NEW ENG. J. MED. 947, 948 (2017) https://www.nejm.org/doi/full/10.1056/NEJMsa1612890 [https://perma.cc/42P8-A9VP].

${ }^{78}$ See Status of State Action on the Medicaid Expansion Decision, KAISER FAM. FouND., https://www.kff.org/health-reform/state-indicator/state-activity-around-expandingmedicaid-under-the-affordable-care act/ [https://perma.cc/M8QZ-HMRH].

${ }^{79}$ In North Carolina, for example, the Republican controlled legislature successfully obtained a court injunction to stop Democratic Governor Roy Cooper from accepting the expansion. Mark Binker, Court Blocks NC Medicaid Expansion Effort, WRAL (Jan. 14, 2017), https://www.wral.com/court-blocks-nc-medicaid-expansion-effort/16434322/

[https://perma.cc/9QZV-JD6Q]. In Maine, a state court ordered Republican Governor Paul LePage to implement the expansion following legislation and a voter referendum demanding that Governor LePage do so. Rachana Pradhan, Court Orders Maine Governor to Expand Medicaid, POLITICO (June 4, 2018), https://www.politico.com/story/2018/06/04/maineexpansion-medicaid-lepage-622824 [https://perma.cc/44S6-YEAG].

${ }^{80}$ As of 2017, Managed Care Organizations "(MCOs) cover nearly two-thirds of all Medicaid beneficiaries.” RACHEL GARFIELD ET AL., KAISER FAM. FOUND., MEDICAID Managed Care Plans and Access to Care: Results from the Kaiser Family Foundation 2017 Survey of Medicaid Managed Care Plans 3, 25 (Mar. 2018), http://files.kff.org/attachment/Report-Medicaid-Managed-Care-March-Plans-and-Accessto-Care [https://perma.cc/8W7N-HGB5].

${ }^{81}$ See, e.g., Sara Rosenbaum et al., Realizing Health Reform's Potential: Medicaid Benefit Designs for Newly Eligible Adults: State Approaches, Commonwealth Fund 3-4 (May 11, 2015), https://www.commonwealthfund.org/publications/issue-briefs/2015/may/ medicaid-benefit-designs-newly-eligible-adults-state-approaches [https://perma.cc/W426DRAD].

${ }^{82}$ Id. at 3; 42 U.S.C. $\S 1396 \mathrm{a}(\mathrm{k})(1)(2012)$.

${ }^{83} I d . \S 18022 ; i d . \S 1396 \mathrm{u}-7$ (b).

${ }^{84}$ Id. $\S 1396 \mathrm{~b}(\mathrm{~m})$; Medicaid Managed Care, CHIP Delivered in Managed Care, and Revisions Related to Third Party Liability, 81 Fed. Reg. 27498, 27501 (May 6, 2016) (to be 
harmonization of federal requirements could prompt more private companies to participate in all three segments of the non-employer-based market (directpurchase plans on the exchanges, privatized Medicaid coverage, and privatized Medicare coverage), as many companies already do. It could also be useful to states interested in pursuing a public-option or single-payer strategy while ensuring compliance with the requirements that govern states' use of federal funds available through Medicaid, Medicare, and the ACA, ${ }^{85}$ as discussed below.

Privatization of public coverage gives private companies something to gain from publicly subsidized access to health care. ${ }^{86}$ It might, therefore, increase the political viability of expansions in Medicaid eligibility, a public option, or a single-payer plan. ${ }^{87}$ But when voters say they approve of Medicare for All or politicians champion a state-level public option, they probably are not envisioning a system where private insurance companies receive capitated payments from the government to administer coverage. Moreover, the benefits of a single-payer system, which I will turn to in Part IV, are less likely to flow from universal coverage provided by a fragmentary network of private insurance companies. As Vermont's successful publicly administered model demonstrates, states need not rely on private insurers (or give up their ability to negotiate directly with providers) to enjoy the savings that accompany managed care. $^{88}$

\section{STRIVING FOR FragmentARY BUT UNIVERSAL COVERAGE}

Prior to the ACA, states such as Hawaii, Massachusetts, and Vermont pioneered efforts to achieve near-universal coverage through a fragmentary combination of public and private coverage, subsidies, penalties, and regulations. The ACA federalizes the health insurance market in some ways: by providing direct federal subsidies and regulating private insurance in ways that effectively mandate cross-subsidization of higher utilizers by those with less need for services. ${ }^{89}$ But the ACA leaves states with considerable leeway to undermine or promote its drafters' goals. ${ }^{90}$ In response to federal retrenchment, several states are considering taking up the mantle of fragmentary, but universal coverage by reinforcing individual and employer mandates, restricting risk-

codified at 42 C.F.R. pts. 431, 433, 438, 440, 457, and 495); Buck, supra note 50, at 11516.

${ }^{85}$ See infra Part II.

${ }^{86}$ Cf. Jacqueline Fox, The Private Insurance Market: Not Very Big and Not Insuring Much, Either, 46 J.L. MED. \& ETHICS (forthcoming 2018) (discussing potential roles for private insurance companies in a federal single-payer system).

${ }^{87}$ HSIAO ET AL., supra note 8 , at xii-xviii.

${ }^{88}$ See Vermont, supra note 73.

${ }^{89}$ See John Brooks et al., Cross-Subsidies: Government's Hidden Pocketbook, 106 GEO. L.J. 1229, 1235-38 (2018).

${ }^{90}$ See Gluck \& Huberfeld, supra note 46, at 2, 5, 20. 
based underwriting in the direct-purchase market, and supporting direct subsidies and other measures to make direct-purchase insurance more affordable. ${ }^{91}$ Some proponents of the fragmentary strategy have proposed that a public option should be offered to anyone eligible to buy insurance on the state health insurance exchanges - or even opened up to broader groups. ${ }^{92}$ The principal legal constraint on states' ability to take up the ACA mantle is ERISA, which preempts many state laws that relate to employee benefits. ${ }^{93}$

\section{A. Replacing the Individual Mandate}

ACA Section 1501's requirement that individuals must purchase insurance if it is affordable for them to do so, or pay a tax penalty ${ }^{94}$ was intended to promote universal coverage and support the financial viability of the directpurchase and small-group markets. ${ }^{95}$ If too many younger, healthier people stay out of the risk pool, confident that they can enter it later when their need is greater, the cost of insurance rises..$^{96}$ As the price increases, the cycle continues. From the outset, the individual mandate made an easy target for popular backlash against the ACA. ${ }^{97}$ The individual mandate survived a years-long onslaught of litigation culminating in NFIB v. Sebelius, ${ }^{98}$ only to be zeroed out in tax reform legislation passed at the end of 2017. ${ }^{99}$ Barring further legislative action, the federal tax penalty will no longer be assessed as of $2019 .{ }^{100}$

${ }^{91}$ See infra Part II.

92 Manatt Health, Medicaid Buy-In: State Options, Design Considerations, AND SECTION 1332 WAIVER IMPLICATIONS 1 (May 2018), https://www.shvs.org/wpcontent/uploads/2018/05/Medicaid_Buyin_-FINAL.pdf [https://perma.cc/6URB-KGHV]; CHAPIN WHITE ET AL., RAND CORP., A COMPREHENSIVE ASSESSMENT OF FOUR OPTIONS FOR FINANCING HEALTH CARE DELIVERY IN OREGON 12-14 (2017), https://www.rand.org/pubs/ research_reports/RR1662.html [https://perma.cc/X65W-NJWS]; see also State Public Option Act, S. 2001, 115th Cong. (2017).

9329 U.S.C. $§ 1144(a)(2012)$

9426 U.S.C. $\$ 5000 \mathrm{~A}(2012)$.

95 Patient Protection and Affordable Care Act, 42 U.S.C. $§ 300 g g$ (2012).

${ }^{96}$ See Christine Eibner \& Evan Saltzman, How Does Enrollment of Young Invincibles Affect Premiums in the ACA Individual Market?, RAND CORP. (Sept. 3, 2015), https://www.rand.org/pubs/research_briefs/RB9812z2.html [https://perma.cc/KND9-MW 9B].

97 Jonathan Chait, The New Republic: The Individual Mandate Backlash, NPR (Dec. 16, 2010), https://www.npr.org/2010/12/16/132104465/the-new-republic-the-individualmandate-backlash [https://perma.cc/W9FA-672Y].

98567 U.S. 519, 569, 574 (2012).

${ }^{99}$ Tax Cuts and Jobs Act of 2017, Pub. L. No. 115-97, § 11081, 131 Stat. 2092 (2017).

${ }^{100}$ Margot Sanger-Katz, Requiem for the Individual Mandate, N.Y. TIMES (Dec. 21, 2017), https://www.nytimes.com/2017/12/21/upshot/individual-health-insurance-mandateend-impact.html [https://perma.cc/WU4F-NPPF]. 
Citing Congressional Budget Office analysis predicting that the elimination of the federal individual mandate penalty will cause premiums to rise, ${ }^{101}$ state legislators quickly began exploring the possibility of adopting state-level penalties for those who forgo purchasing insurance even though it would be affordable for them to do so. ${ }^{102}$ In February of 2018, The Wall Street Journal reported that at least nine states were considering adopting their own versions of the individual mandate. ${ }^{103}$ As of August 2018, however, only New Jersey, Vermont, and Washington, D.C., had done so. ${ }^{104}$

\section{B. Replacing the Employer Mandate}

ACA Section 1513 mandated that employers with fifty or more employees must provide adequate health benefits at an affordable price or pay a penalty. ${ }^{105}$ This pay-or-play mandate was intended to "discourage employers" from relying on government-subsidized coverage for employees on the individual market. ${ }^{106}$ Implementation has been rocky. The Obama Administration repeatedly delayed the penalty. ${ }^{107}$ Congressional Republicans and President Trump have both

101 See generally Cong. Budget Office, Repealing the Individual Health INSURANCE MANDATE: AN UPDATED ESTIMATE (2017), https://www.cbo.gov/system/files/ 115th-congress-2017-2018/reports/53300-individualmandate.pdf [https://perma.cc/9XKA$\mathrm{MNHH}]$ (noting that premiums would rise by around $10 \%$ each year).

102 See Jason Levitis, Model Legislation for State Individual Mandate (Feb. 21, 2018) (unpublished legislation proposal, Woodrow Wilson School of Public \& International Affairs, Princeton University), https://www.shvs.org/resource/model-legislation-for-stateindividual-mandate/ [https://perma.cc/5D85-YCQJ].

${ }^{103}$ Stephanie Armour, States Look at Establishing Their Own Health Insurance Mandates, WALL ST. J. (Feb. 4, 2018), https://www.wsj.com/articles/states-look-atestablishing-their-own-health-insurance-mandates- $1517659200 ? \mathrm{mod}=\mathrm{e} 2 \mathrm{tw}$

[https://perma.cc/7SV9-2JQT]; see also Levitis, supra note 102; Mattie Quinn, State Efforts to Bring Back Obamacare's Individual Mandate Stall, GovernING (Mar. 5, 2018), http://www.governing.com/topics/health-human-services/gov-obamacare-individualmandate-tax-law-states.html [https://perma.cc/7QNS-TLQX].

${ }^{104}$ B22-0753 Council of the District of Columbia (D.C. 2018); S. 1877, 218th Leg., Reg. Sess. (N.J. 2018); H.R. 696, 2018 Gen. Assemb., Reg. Sess. (Vt. 2018); see also Jenna Portnoy, Senate Blocks Effort to Kill D.C.'s Version of Affordable Care Act's Individual Mandate, WASH. POST (Aug. 2, 2018), https://www.washingtonpost.com/local/dcpolitics/thats-not-democracy-senate-kills-effort-to-stymie-dcs-version-of-the-affordablecare-act/2018/08/02/246e2c94-966d-11e8-810c-5fa705927d54 story.html

[https://perma.cc/SAC5-WUZT] (discussing the Senate's rejection of a recent measure that would have reversed Washington, D.C.'s, version of the individual mandate).

10526 U.S.C. $\$ 4980 \mathrm{H}(\mathrm{a})-(\mathrm{c})(2012)$. Employers must offer coverage that pays, on average, for at least $60 \%$ of covered expenses and the cost to the employee may not exceed $9.5 \%$ of household income. Id. $\S 36 \mathrm{~B}(\mathrm{c})(2)(\mathrm{C})$.

106 Brendan S. Maher, Unlocking Exchanges, 24 ConN. INS. L.J. 125, 147 (2017).

107 Juliet Eilperin \& Amy Goldstein, White House Delays Health Insurance Mandate for Medium-Size Employers Until 2016, WASH. POST (Feb. 10, 2014), https://www.washingtonpost.com/national/health-science/white-house-delays-health- 
expressed a desire to repeal it. ${ }^{108}$ If the federal employer mandate is repealed or under-enforced, could a state legislature minimize the burden of supporting subsidies in the direct-purchase market by adopting a state-level employer mandate in its place? The key legal question is whether a state employer mandate would be preempted by ERISA.

ERISA establishes minimum standards for employee pension and welfare benefit plans (including health plans), but provides relatively little in the way of affirmative protections for enrollees in employer-based health coverage. ${ }^{109}$ Its principal impact on employer-based health coverage is deregulatory. ${ }^{110}$ Section 514 of ERISA expressly preempts state laws that "relate to" an employee benefit plan governed by ERISA. ${ }^{111}$ Congress intended to permit multi-state employers to offer uniform benefits without regard to regulations that vary from state to state. ${ }^{12}$ Employers who self-insure (meaning that they bear the financial risk themselves rather than purchasing health insurance for their employees) enjoy particular protection from state regulation under ERISA. ${ }^{113}$ Although the statute's savings clause provides that state laws that "regulate insurance" are saved from preemption, ${ }^{114}$ the statute specifies that self-insuring employers may not be deemed insurers for the purposes of the savings clause. ${ }^{115}$

The Supreme Court has not addressed preemption of state pay-or-play mandates and lower court precedents are split. ${ }^{116}$ Hawaii, which adopted a mandate that all employers must provide health benefits in 1974, ${ }^{117}$ sought and received a statutory exemption from ERISA preemption. ${ }^{118}$ The Massachusetts

insurance-mandate-for-medium-sized-employers-until-2016/2014/02/10/ade6b344-927911e3-84e1-27626c5ef5fb_story.html [https://perma.cc/KTT2-DDRS].

108 Alan Rappeport, Trump Says He Got Rid of Obamacare. The I.R.S. Doesn't Agree, N.Y. TIMES (May 6, 2018), www.nytimes.com/2018/05/06/business/trump-obamacareirs.html [on file with Ohio State Law Journal].

109 See Brendan S. Maher, Regulating Employment-Based Anything, 100 MinN. L. REV. 1257,1270 (2016).

110 Id.

11129 U.S.C. § 1144(a) (2012). Plans governed by ERISA include all employer-based health plans except those offered by government employers and churches. Id. § 1003(b)(1)(2).

112 See 514 U.S. 645, 656-57 (1995).

113 See 29 U.S.C. $\$ 1144(\mathrm{~b})(2)(\mathrm{B})$.

114 Id. $\S 1144(\mathrm{~b})(2)(\mathrm{A})$.

115 Id. § 1144(b)(2)(B).

${ }^{116}$ See Samuel C. Salganik, What the Unconstitutional Conditions Doctrine Can Teach Us About ERISA Preemption: Is It Possible to Consistently Identify "Coercive" Pay-OrPlay Schemes, 109 ColuM. L. ReV. 1482, 1482, 1484 (2009).

117 Prepaid Health Care Act of 1974, HaW. REv. STAT. ANN. §§ 393-11, 393-33 (West 2018).

11829 U.S.C. § 1144(b)(5)(A); Nicholas Bagley, Federalism and the End of Obamacare, 127 YALE L.J.F. 1, 15 (2017). 
employer mandate component of Romneycare ${ }^{119}$ was not challenged in court, but similar pay-or-play employer mandates in Maryland and San Francisco were. ${ }^{120}$ In 2007, the Fourth Circuit struck down Maryland's mandate requiring certain employers (only Wal-Mart qualified) to commit at least $8 \%$ of payroll to employee health benefits or else pay the same amount to a state fund supporting public coverage. ${ }^{121}$ The court found that the Maryland law "directly regulates employers' structuring of their employee health benefit plans"122 and that "a proliferation of similar laws in other jurisdictions would force Wal-Mart or any employer like it to monitor these varying laws and manipulate its healthcare spending to comply with them." 123 In 2009, the Ninth Circuit upheld San Francisco's mandate requiring employers to make health care expenditures for their employees or pay a penalty to the city. ${ }^{124}$ The court found that an ERISA employer may be influenced by the city ordinance to "adopt or to change an ERISA plan ... because, when faced with an unavoidable obligation to make a payment at a certain level, it may prefer to make that payment to an ERISA plan. However, . . . such influence is entirely permissible." 125 The issue became moot when the ACA federalized the employer mandate ${ }^{126}$ so the question remains unresolved. The fact that Congress understood Hawaii's mandate to require a special statutory exemption bolsters the argument that, in the absence of such an exemption from Congress, other states' mandates are preempted. ${ }^{127}$ As Nicholas Bagley has argued: "At a minimum, the unsettled scope of ERISA preemption will give states pause. Why take the political hit for imposing a new 'employer mandate' when the courts will probably invalidate it anyhow?"128

\section{Restricting Risk-Based Underwriting in the Direct-Purchase Market}

Historically, market failures, inadequate consumer information, and overrepresentation of less-healthy prospective insureds in the direct-purchase market drove up the cost and limited the quality of coverage available to people who lacked access to employer-based insurance and were not eligible for public

119 An Act Providing Access to Affordable, Quality, Accountable Health Care, ch. 58, 2006 Mass. Acts 77 (codified as amended in scattered sections of the Massachusetts General Laws).

${ }^{120}$ See Salganik, supra note 116, at 1482.

121 Retail Indus. Leaders Ass'n v. Fielder, 475 F.3d 180, 183 (4th Cir. 2007).

122 Id. at 195 .

$123 \mathrm{Id}$. at 197.

124 Golden Gate Rest. Ass'n v. City and Cty. of S. F., 546 F.3d 639, 661 (9th Cir. 2008).

$125 \mathrm{Id}$. at 656 .

126 See Bagley, supra note 118, at 14.

127 See id. at 14-15. Hawaii's Section 1332 waiver to reconcile the ACA with the state's employer mandate was approved in December 2016. ManATt HeAlth, 1332 State Innovation Waivers Under the Trump Administration, St. HeAlth Reform AssistanCE NETWORK 21 (Apr. 12, 2017), http://www.statenetwork.org/wp-content/uploads/2017/04/ 1332-Waiver-Webinar-4-12-17_Final.pdf [https://perma.cc/95ZE-GE89].

${ }^{128}$ Bagley, supra note 118 , at 15 . 
coverage. ${ }^{129}$ Additionally, people with higher expected health care costs due to pre-existing conditions, family history, or other factors (such as being a woman) could be charged premiums that were prohibitively expensive, offered terms of coverage that left them with significant financial exposure, or denied coverage altogether. ${ }^{130}$

Under the ACA, direct-purchase insurance plans are bought, sold, regulated, and subsidized through health insurance exchanges. ${ }^{131}$ The ACA requires these plans to cover the essential health benefits package. ${ }^{132}$ All health plans, including those in the direct-purchase market, are subject to a guaranteed issue requirement, which prohibits them from excluding anyone based on factors related to health status. ${ }^{133}$ They are sharply limited in their ability to charge differential premiums based on factors related to health status, ${ }^{134}$ and they are prohibited from excluding treatment for pre-existing conditions. ${ }^{135}$ The ACA regulations restricting risk-based underwriting - colloquially referred to as protections for people with preexisting conditions - are crucial for many individuals who would otherwise be uninsurable in the private market. ${ }^{136}$ As their critics appreciate, these regulations effectively bring about a hidden crosssubsidization of high utilizers (who pay a rate lower than actuarial predictions would dictate) by low utilizers (who pay more than actuarial predictions would dictate). ${ }^{137}$

129 Jon R. Gabel et al., More Than Half of Individual Health Plans Offer Coverage That Falls Short of What Can Be Sold Through Exchanges as of 2014, 31 HeALTH AFFAIRS 133940 (2012); Gary Claxton et al., What Do They Mean When They Talk About Pre-Existing Health Conditions?, KAISER FAM. FOUND. (Oct. 19, 2012), http://kff.org/healthreform/perspective/what-do-they-mean-when-they-talk-about-pre-existing-healthconditions/ [https://perma.cc/X7FQ-B5UA].

${ }^{130}$ Although people enrolled in employer-based coverage have been protected from discrimination based on health status for decades, in the direct-purchase market, risk-based underwriting was the norm prior to the ACA. Claxton et al., supra note 129.

${ }^{131}$ Patient Protection and Affordable Care Act, Pub. L. No. 111-148, §§ 1311-24 Stat. 120 pts. II, III (2010) (codified as amended in scattered sections of 42 U.S.C.).

13242 U.S.C. $§ 300 \mathrm{gg}-6$ (a) (2012).

133 Guaranteed issue, community rating, and restrictions on exclusions for preexisting conditions were already in place for group plans under the Health Insurance Portability and Accountability Act. 42 U.S.C. $\S 300 \mathrm{gg}$ (2012).

13442 U.S.C. $\S 300 \operatorname{gg}(\mathrm{a})(1)(\mathrm{A})-(\mathrm{B})$.

${ }^{135} \mathrm{Id}$. § 300gg-3(a).

${ }^{136}$ See Gary Claxton et al., Pre-Existing Conditions and Medical Underwriting in the Individual Insurance Market Prior to the ACA, KAISER FAM. FounD. (Dec. 12, 2016), https://www.kff.org/health-reform/issue-brief/pre-existing-conditions-and-medical-

underwriting-in-the-individual-insurance-market-prior-to-the-aca/ [https://perma.cc/VP6RCFYB].

${ }^{137}$ See, e.g., Tom Miller, The Concentration and Persistence of Health Care Spending, CATO INST. 28, 30 (Winter 2017-18), https://object.cato.org/sites/cato.org/files/serials/files /regulation/2017/12/regulation-v40n4-4.pdf [https://perma.cc/88WK-SE67]. 
Although the underwriting regulations are the most popular component of the ACA, they are the subject of ongoing litigation and threats of repeal. ${ }^{138}$ If federal restrictions on risk-based underwriting are rolled back, can states step in? At least as far as the direct-purchase market is concerned, ${ }^{139}$ no obvious legal obstacle stands in the way of state-level underwriting reforms. Several states, including Massachusetts ${ }^{140}$ and Vermont, ${ }^{141}$ already had some form of protection for people with preexisting conditions in place prior to the ACA. States could face political pressure to forgo underwriting regulations out of fear that insurers would abandon their exchanges for greener pastures. On the other hand, the groundswell of political support for pre-existing conditions protections triggered by Republican repeal proposals in 2017 could bolster state legislators' political courage.

\section{Promoting Access to Affordable Direct-Purchase Insurance}

States have considerable authority to shape access to direct-purchase insurance on their health insurance exchanges through the application of federal subsidies, regulatory review of premium increases, and administrative waivers that open up the exchanges to new populations. The ACA permits states to establish their own exchanges with minimal federal involvement, ${ }^{142}$ but most states have opted not to do so, allowing HHS to step in and do it for them or in partnership with them. ${ }^{143}$ States that run their own exchanges enjoy broader authority to reduce the impact of federal retrenchment on residents. In particular, some states are using their authority over premium increases to undermine the Trump Administration's efforts to cut federal subsidies. ${ }^{144}$

In the ACA's "three-legged stool" approach to increasing enrollment in the direct-purchase market, the individual mandate and underwriting reforms were

138 See, e.g., Vann R. Newkirk II, The Federal Government Abandons the Most Popular Part of the ACA, THE ATLANTIC (June 8, 2018), https://www.theatlantic.com/politics/archive /2018/06/aca-preexisting-conditions-doj/562442/ [https://perma.cc/4X5V-2383].

${ }^{139}$ Underwriting restrictions in the group market are part of an older law- the Health Insurance Portability and Accountability Act of 1994. See generally 42 U.S.C. § 300gg-3(a) (2012) (prohibiting group-market insurers from excluding based on preexisting conditions). If the group-market underwriting regulations in HIPAA were repealed, state efforts to replace them would be preempted by ERISA, at least with respect to plans offered by private, non-church employers. 29 U.S.C. § 1003(b)(1)-(2) (2012).

140 See Mass. GEN. LAWs ANN. ch. 176J, § 5 (West 2014).

141 See Vt. StAT. AnN. tit. 33, § 1825 (West 2014).

14242 U.S.C. $\S 18031$.

143 See State Health Insurance Marketplace Types, 2018, KAISER FAM. FOUND., https://www.kff.org/health-reform/state-indicator/state-health-insurance-marketplace-types [https://perma.cc/X3HR-LPH4] (describing how fourteen states have state-based marketplaces as of July 2014).

${ }^{144}$ See Robert E. Moffit, States Are Offering Relief from Rising Health Care Costs. Here's How Congress Can Help, Heritage Found. (May 24, 2018), https://www.heritage.org/health-care-reform/commentary/states-are-offering-relief-risinghealth-care-costs-heres-how [https://perma.cc/G3PX-QEE5]. 
supplemented by subsidies to reduce out-of-pocket costs. ${ }^{145}$ The ACA's drafters established two main subsidies: premium assistance tax credits (PTCs) and costsharing reduction payments (CSRs). ${ }^{146}$ First, PTCs reduce the price of directpurchase insurance for people with household incomes between $100 \%$ and $400 \%$ FPL who do not have access to public programs or affordable employerbased coverage. ${ }^{147}$ Plans sold on the exchanges are classified into four tiers (platinum, gold, silver, and bronze) based on their actuarial value - a measure of the financial protection afforded by a plan, determined by the combination of its deductible, copayments, and coinsurance, calculated as the percentage of covered costs that the plan pays for, on average. ${ }^{148}$ By statute, the amount of the PTC subsidy is tied directly to the price of the second lowest-cost silver-tier plan on the exchange and is calculated on a sliding scale based on income. ${ }^{149}$ Second, Section 1402 of the ACA requires insurers offering plans on the exchanges to reduce deductibles, copayments, and coinsurance for people with household incomes between $100 \%$ and $400 \%$ of FPL who purchase a plan from the silver tier. ${ }^{150}$ To offset the costs, the statute directs the HHS Secretary to make CSR payments to insurers equal to the value of the reduction. ${ }^{151}$ Unlike PTCs, which are funded through an automatic appropriation, CSRs are subject to annual appropriations through the budget process, making them vulnerable to shifts in political control. ${ }^{152}$ In 2017, the Trump Administration halted payments, which

145 Jonathan Gruber, Health Care Reform Is a "Three-Legged Stool:" The Costs of Partially Repealing the Affordable Care Act, CTR. FOR AM. Progress (Aug. 5, 2010), https://www.americanprogress.org/issues/healthcare/reports/2010/08/05/8226/health-carereform-is-a-three-legged-stool/ [https://perma.cc/EBC9-6SV2].

14626 U.S.C. $\S 36 \mathrm{~B}(\mathrm{~b})(2012) ; 42$ U.S.C. $\S 18071$. In addition to subsidies, the ACA included three key provisions aimed at redistributing funds from direct-purchase plans that enroll low-risk populations to those that enroll high-risk populations: reinsurance, risk corridors, and risk adjustment payments. 42 U.S.C $\S \S 18061-18063$. The first two provisions were intended to be temporary and expired in 2016. In 2018, the Trump Administration halted risk adjustment payments (which were intended to be permanent) in response to a lower court holding. See e.g., Dylan Scott, The Trump Administration Freeze on Obamacare's Risk Adjustment Payments, Explained, Vox (July 9, 2018), https://www.vox.com/policy-and-politics/2018/7/9/17549812/trump-freeze-obamacarerisk-adjustment-payments [https://perma.cc/75HZ-6YGV].

14726 U.S.C. $\$ 36 \mathrm{~B}(\mathrm{~b})(3)(\mathrm{A}) ; 42$ U.S.C. $\S 18081$; id. $\S 18082$.

14826 U.S.C. $\$ 36 \mathrm{~B}(\mathrm{~b})$; see also KAISER FAMILY FOUND., WhAT THE ACTUARIAL VALUES IN THE AFFORDABLE CARE ACT MEAN 2 (Apr. 2011), https://kaiserfamilyfoundation .files.wordpress.com/2013/01/8177.pdf [https://perma.cc/FK5H-MRD5].

14942 U.S.C. $\S 18022(\mathrm{~d})(2012)$.

${ }^{150} \mathrm{Id}$. $\S 18071(\mathrm{~b})-(\mathrm{c})$.

${ }^{151} \mathrm{Id}$ § 18071(c)(3); id. § 18082(c)(3).

152 See Letter from Gen. Jeff Sessions Attorney Gen., U.S. Dep't of Justice to Treasury Sec'y Steven Mnuchin, Sec'y, U.S. Dept. of Treasury and Don Wright, Sec'y, U.S. Dept. of Health and Human Services (Oct. 11, 2017), https://www.hhs.gov/sites/default/files/csrpayment-memo.pdf [https://perma.cc/2QEB-44UY]. 
the Obama Administration had previously been making via a process that was challenged by House Republicans in the courts. ${ }^{153}$

In addition to facilitating the application of ACA subsidies to purchases on their health insurance exchanges, states play an important role in reviewing proposed premium increases for exchange plans. When CSR payments were threatened, several states used this authority to minimize the impact on their residents. ${ }^{154}$ Because PTCs are automatically appropriated and tied to silverplan premiums, insurance regulators in several states worked with insurers to load the additional expense of reducing cost sharing into the premiums of silver plans. ${ }^{155}$ This silver loading strategy meant that the federal government continued to bear the costs and low-income residents continued to enjoy access to coverage with reduced cost sharing. ${ }^{156}$

A few states are exploring additional steps via administrative waiver that would stabilize premiums on their exchanges and open up access to new populations. Section 1332 of the ACA provides for state innovation waivers, which may release states from certain statutory requirements as part of a statewide plan that would, in the HHS Secretary's judgment, promote the ACA's goals. ${ }^{157}$ Ordinarily the PTCs and CSRs (were they to be reinstated) are transmitted directly from the federal government to insurers. A 1332 waiver may permit funds to pass through to the state instead. ${ }^{158}$ Statutory criteria require the state plan to provide coverage as comprehensive as that ensured by the ACA to at least as many residents while avoiding any increase in federal spending. ${ }^{159}$ As for Medicaid waivers, ACA waiver applications require the state to enact authorizing legislation and provide opportunities for public comment. 160

153 See generally U.S. House of Reps. v. Burwell, 185 F. Supp. 3d 165, 165 (D.D.C. 2016) (holding that the "ACA did not permanently appropriate money for reimbursements to health insurers for reductions of deductibles, co-pays, and other means of cost-sharing").

${ }^{154}$ See Moffit, supra note 144.

155 Allison K. Hoffman, Cost-Sharing Reductions, Technocrat Tinkering, and MarketBased Health Policy, 46 J.L. MED. \& ETHICS (forthcoming 2018).

156 See Margo Sanger-Katz \& Kevin Quealy, When Silver Costs More Than Gold: How Trump's Actions Have Scrambled Insurance Prices, N.Y. TIMES (Oct. 27, 2017), https://www.nytimes.com/2017/10/27/upshot/when-silver-costs-more-than-gold-howtrumps-actions-have-scrambled-insurance-prices.html [on file with Ohio State Law Journal].

15742 U.S.C. $§ 18052(a)-(b)$ (2012); Heather Howard \& Galen Benshoof, State Innovation Waivers: Redrawing the Boundaries of the ACA, 40 J. HEALTH POL. POL'Y \& L. 1203, 1204-05 (2015); Sarah Lueck \& Jessica Schubel, Understanding The Affordable Care Act's State Innovation ("1332”) Waivers, CTR. ON BUdGET \& POL'Y PRIORITIES 3-4 (Sept. 5, 2017), https://www.cbpp.org/sites/default/files/atoms/files/2-5-15health1.pdf [https://perma.cc/TF83-YET7]; John E. McDonough, Wyden's Waiver: State Innovation on Steroids, 39 J. HeAlth POL. POL'Y \& L. 1099, 1100-01 (2014).

15842 U.S.C. $\S 18052(\mathrm{a})(3)(2012)$.

${ }^{159} I d$. $\S 18052(\mathrm{~b})(1)$.

16031 C.F.R. $\S 33.100$ (a)(1) (2017). 
Several states have obtained or are pursuing 1332 waivers. ${ }^{161}$ In 2017 , Alaska received a Section 1332 waiver to redirect PTC funds toward a state reinsurance program that reimburses private insurers for claims paid to treat enrollees with designated high-cost health conditions. ${ }^{162}$ Prior to the 2016 election, California was pursuing a waiver to allow undocumented immigrants to purchase unsubsidized insurance coverage on its exchange. ${ }^{163}$ In Oregon, state officials are considering subsidizing private health insurance coverage for all Oregon residents (including undocumented immigrants, excluding Medicare enrollees) using a combination of state and federal funds. ${ }^{164}$ The proponents of this strategy call it the Oregon Health Care Ingenuity Plan, 165 but Obamacare for All would be a more informative, if less popular, label.

\section{E. Allowing Residents to Buy into a Public Option}

Dissatisfaction with high out-of-pocket costs and subsidization of for-profit insurers under the ACA has prompted some on the left to argue for expanding access to direct-purchase insurance (while maintaining the fragmentary system) by offering a public option. ${ }^{166}$ Although a public option was initially considered as part of the ACA, it was ultimately stripped from the bill. ${ }^{167}$ As the ACA came

161 See Tracking Section 1332 State Innovation Waivers, KAISER FAM. FounD. (July 30, 2018), https://www.kff.org/health-reform/fact-sheet/tracking-section-1332-state-innovation -waivers/ [https://perma.cc/63S7-XETR]; Heather Howard, More States Looking to Section 1332 Waivers, St. Health \& VAlue Strategies (July 30, 2018), https://www.shvs.org/more-states-looking-to-section-1332-waivers/ [https://perma.cc/7AD 5-KTUW].

162 Letter from Bill Walker, Governor, Alaska, to Linda Rashid, Policy Advisor, CMS (July 31, 2017), https://www.cms.gov/CCIIO/Programs-and-Initiatives/State-InnovationWaivers/Downloads/Alaska-STCs-signed-by-Treasury.pdf [https://perma.cc/7SHH-D28S]; Alaska: State Innovation Waiver under Section 1332 of the PPACA, CTR. FOR MEDICARE \& MediCAID SERVS. (July 11, 2017), https://www.cms.gov/CCIIO/Programs-and-Initiatives/ State-Innovation-Waivers/Downloads/Fact-Sheet.pdf [https://perma.cc/FTU2-NTYU].

163 Sen. Bill 10, 2015-2016 Reg. Sess. (Cal. 2016); see also Letter from Peter V. Lee, Exec. Dir., Covered Cal., to Sylvia Burwell, Sec'y, U.S. Dep't of Health and Human Services (Dec. 16, 2016), https://www.cms.gov/CCIIO/Programs-and-Initiatives/State-InnovationWaivers/Downloads/Covered-California-Section-1332-Waiver-Application-12-16-16.pdf [https://perma.cc/TUF5-FDW8]; Letter from Peter V. Lee, Exec. Dir., Covered Cali., to Kevin J. Counihan, Dir. Of Marketplace \& Exec. Officer, HHS (Jan. 18, 2017), http://hbex.coveredca.com/stakeholders/Covered\%20California $\% 201332 \% 20$ Waive r/1332\%20Application\%20Withdrawal\%20Request $\% 2001 \% 2018$.pdf

[https://perma.cc/A7KW-E3ZS]; Wendy E. Parmet et al., Immigration and Health: Law, Policy, and Ethics, 45 (SUPP. 1) J.L. MED. \& ETHICs 55, 56 (2017).

164 WHITE ET AL., supra note 92, at 12-14.

165 Id.

166 Peter Sullivan, Dem Senators Unveil Expanded Public Option for Health Insurance, THE HILl (Apr. 18, 2018), http://thehill.com/policy/healthcare/383764-dem-senatorsunveil-expanded-public-option-for-health-insurance [https://perma.cc/EU48-C3XH].

${ }^{167}$ Mariah McGill \& Gillian MacNaughton, The Struggle to Achieve the Human Right to Health Care in the United States, 25 S. CAL. INTERDISC. L.J. 625, 659 (2016) ("[T] he 
under threat, Democratic lawmakers again turned to the possibility of a public option, centered around opening up access to Medicare, sometimes referred to as Medicare buy-in or (confusingly) Medicare for all. ${ }^{168}$ At the state level, legislators (barring a veto by the governor) could offer their Medicaid plans (currently financed by a mix of state and federal funds), non-Medicaid public plans (currently financed by state funds), or state employee benefit plans (currently financed by state funds and premiums) for purchase on the exchange. ${ }^{169}$ They could limit access to residents who are eligible to purchase insurance on the exchange under federal law or they could open up the buy-in to other groups, such as undocumented immigrants or people who have access to employer-based coverage that qualifies as affordable under the ACA. ${ }^{170}$ Most state-level public option proposals would involve leveraging Medicaid in some way-by using the state's Medicaid provider network, reimbursement rates, or

public option - a government run plan that people could choose instead of private plans on the exchange - was supported by 77 percent of the population but was ultimately stripped from the [ACA] bill.") (citing Jordan Fabian, Pelosi: Public Option Will Not Be in Health Bill Despite Liberal Efforts to Revive It, The HILL (Mar. 12, 2010), http://thehill.com/blogs/blog-briefing-room/news/86447-pelosi-public-option-will-not-bein-health-bill [https://perma.cc/TMJ7-EPEG]).

168 Dylan Scott, The "Pleasant Ambiguity" of Medicare-for-All in 2018, Explained, Vox (July 2, 2018), https://www.vox.com/policy-and-politics/2018/7/2/17468448/medicare -for-all-single-payer-health-care-2018-elections [https://perma.cc/99LQ-BZSZ]; see also Medicare-X Choice Act of 2017, S. 1970, 115th Cong. (2017).

169 Patricia Boozang et al., Manatt Health, Medicaid Buy-In: State Options, DESign CONSIDERATIONS, AND SECTION 1332 WAIVER IMPLiCATIONS 1 (May 2018), https://www.shvs.org/wp-content/uploads/2018/05/Medicaid_Buyin_-FINAL.pdf [https://perma.cc/6URB-KGHV]. Several states already have limited buy-in programs in place for certain children with special needs, but that coverage acts primarily as a supplement to private insurance, covering services that private insurers typically do not. Medicaid BuyIns, CTR. FOR ADVANCING HEALTH POL'Y \& PRACTICE, http://cahpp.org/project/the-catalystcenter/financing-strategy/medicaid-buy-ins/ [https://perma.cc/YTR3-XV82]. Section 1331 of the ACA gives states the option of seeking the HHS Secretary's approval to implement a state-contracted basic health plan (BHP) to cover residents with household incomes up to 200\% FPL. 42 U.S.C. $\S 18051$ (2012). New York and Minnesota have taken advantage of this option, which exists outside of Medicaid and the exchanges, and additional states are considering doing so. Jennifer Tolbert et al., Improving the Affordability of Coverage Through the Basic Health Program in Minnesota and New York, KAISER FAM. FOUND. (Dec. 2016), https://www.kff.org/health-reform/issue-brief/improving-the-affordability-ofcoverage-through-the-basic-health-program-in-minnesota-and-new-york/

[https://perma.cc/WDM6-SN75]; see, e.g., S. Memorial 3, 53rd Leg., 2d Sess. (N.M. 2018).

170 The Nevada bill directed the state director of health and human services to establish a plan "within Medicaid" and make it available "to any person who is not otherwise eligible for Medicaid." Assemb. B. 374, 2017 Leg., 79th Reg. Sess. (Nev. 2017). Similar bills introduced in Wisconsin and Minnesota have defined the population to be offered the buyin option differently. BadgerCare Plus offers assistance for childless adults as well as demonstration project purchase options, Assemb. B. 449, 103d Leg., Reg. Sess. (Wis. 2017). MinnesotaCare offers a separate purchase option for individuals exceeding the MinnesotaCare income eligibility limit; federal waiver authorization. S. File 58, 90th Leg., 1st Reg. Sess. (Minn. 2017) 
claims administration infrastructure, or offering benefits modeled after the state's Medicaid plan. ${ }^{171}$ What this would look like on the ground depends on the extent to which a state's existing Medicaid program has been privatized. The functions involved in plan administration - such as overseeing provider networks, negotiating reimbursement formulas, administering claims, and designing benefit packages - could be performed by a state agency, private contractors, or a combination of the two.

Typically, progressive states like Vermont ${ }^{172}$ and Oregon, ${ }^{173}$ where the legislature and executive are both Democrat-controlled, are discussing Medicaid buy-in proposals. States with Democratic legislatures and Republican executives, such as New Mexico ${ }^{174}$ and Nevada, ${ }^{175}$ are also exploring the idea. In 2017, Nevada's legislature voted to allow any of the state's residents to purchase Medicaid at a price considerably lower than private insurance premiums on the state's exchange. ${ }^{176}$ Those who qualify for federal subsidies for the purchase of private insurance on the exchange could use those subsidies to purchase Medicaid coverage instead. ${ }^{177}$ The bill's sponsor specifically noted that the proposal was a reaction to the "mixed messages coming from our current federal administration." 178 In addition to undermining the viability of the ACA exchanges, there were threats from the federal government to terminate the Medicaid expansion, which Nevada had adopted. ${ }^{179}$ The buy-in proposal might have allowed residents living between $100 \%$ and $138 \%$ of FPL to keep their Medicaid coverage by switching from combined federal-state financing under the Medicaid statute to coverage subsidized by ACA tax credits. ${ }^{180}$ Ultimately, however, the bill was vetoed by the state's Republican governor, amid opposition from hospitals and other groups. ${ }^{181}$

Some proponents support giving residents the option of purchasing publicly administered health coverage as an end in itself. A public option could make coverage more affordable for people who are not eligible for ACA subsidies. Competition from a public plan offering lower deductibles and copays for enrollees at lower administrative costs could prompt private insurers to compete

${ }^{171}$ BoOZANG ET AL., supra note 169, at 1-6.

172 HSIAO ET AL., supra note 8, at xii.

173 WHITE ET AL., supra note 92, at 14-16.

174 N.M. S. Memorial 3.

175 Nev. Assemb. B. 374.

176 Alison Kodjak, Nevada May Become First State to Offer Medicaid to All, Regardless of Income, NPR (June 13, 2017), https://www.npr.org/sections/health-shots/2017/06/13/5 32783189/nevada-may-become-first-state-to-offer-medicaid-to-all-regardless-of-income [https://perma.cc/C6TY-JNBD].

177 Id.

178 Id

${ }^{179} \mathrm{Id}$.

180 Nev. Assemb. B. 374.

${ }^{181}$ David Montero, Nevada Governor Vetoes Medicaid-for-All Bill, L.A. TIMES (June 17, 2017), http://www.latimes.com/nation/la-na-nevada-medicaid-2017-story.html [https://perma.cc/5QBZ-B9FK]. 
by becoming more efficient and improving the financial protection offered by their coverage. ${ }^{182}$ Aside from promoting competition on the exchanges, a public option could give consumers more options in counties where only one private insurer participates in the exchange. ${ }^{183}$ Other public option proponents openly argue that it is a means to the end of single-payer health care, ${ }^{184}$ a topic I will turn to in the next section. These goals may not be easy to harmonize. For example, if the public option is more affordable than private coverage, the result could be less competition, not more. Indeed, that may be the result envisioned by proponents who see the public option as a glide path to single-payer health care. ${ }^{185}$

The drafters of public option bills have assumed that one or more administrative waivers could be necessary. ${ }^{186}$ A Medicaid Section 1115 waiver could be required for any public option that would affect a state's Medicaid plan. An ACA Section 1332 waiver could be required to allow those who are eligible for premium assistance tax credits to apply them toward the purchase of the public option. Whether a state could offer a public option for sale on its exchange in the absence of permission from HHS or facilitating legislation from Congress is a critical question worth exploring in detail.

\section{Complying with Federal Medicaid Law}

Whether a Medicaid Section 1115 waiver would be required depends on how the state designs its public option. There are two issues: (1) ensuring that

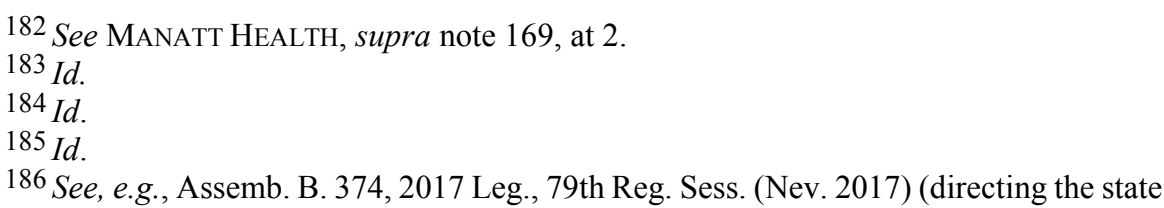
health and human services director to "apply to the Secretary of the United States Department of Health and Human Services for any necessary waiver pursuant to 42 U.S.C. $\S 1315$ or $\S 18052$, as applicable"); Assemb. B. 449, 103rd Leg., Reg. Sess. (Wis. 2017) (directing the state department of health services "if required, [to] request a waiver from or submit amendments to the state Medical Assistance plan to the secretary of the federal department of health and human services to establish a program that allows individuals with income [above the eligibility threshold for Medicaid under federal law and the state's existing waiver] the option of purchasing coverage [currently available to Medicaid enrollees] instead of purchasing an individual health plan through private insurance"); S. File 58, 90th Leg., 1st Reg. Sess. (Minn. 2017) (directing "the commissioner of human services [to] seek necessary federal waiver authority to establish a program that allows individuals with income above the maximum income eligibility limit [for Medicaid under federal law and the state's existing waiver], the option of purchasing coverage through MinnesotaCare instead of purchasing a qualified health plan [on the state's exchange] or an individual health plan offered outside of [the state exchange]"; to "seek necessary federal waiver authority . . f for individuals ... to use advanced tax credits and cost-sharing credits, if eligible, to purchase this option" and to "seek necessary federal waiver authority to permit the MinnesotaCare purchase option to be offered through [the state exchange] as a coverage option and to be compared with qualified health plans offered through [the state exchange]"). 
the coverage provided to federally eligible enrollees comports with federal requirements and (2) ensuring that federal Medicaid funds are not used to crosssubsidize buy-in enrollees.

First, in the absence of an 1115 waiver, the state would certainly have to ensure that federally eligible enrollees continue to be covered for services mandated by federal law. State lawmakers have attempted to address this issue in broad strokes. For example, Nevada's public option bill specified that federally eligible Medicaid enrollees would continue to receive the benefits to which they are entitled under federal law, while buy-in enrollees would receive the same benefits, with the exception of coverage for non-emergency medical transportation. ${ }^{187}$ There are almost certainly other Medicaid benefits that Nevada policymakers would eventually have denied to buy-in enrollees, even though some federally eligible enrollees are entitled to them - such as long-term care coverage, adult dental and vision, and social worker coordination services.

Second, the state would have to ensure that buy-in enrollees are in a separate risk pool from federally-eligible Medicaid enrollees, to prevent cross-subsidy. Combining the two groups into a single risk pool would certainly require an 1115 waiver. As the Nevada bill's findings note, the Medicaid statute prohibits the use of federal Medicaid funds to finance expenses that are not authorized by statute or waiver. ${ }^{188}$ Cross-subsidy is the entire point of risk pooling, the process whereby revenues are pooled together before being transferred to the entity (in this case a state agency) that will purchase coverage (from private companies) or individual services (from health care providers) for enrollees. By combining the funds, pooling spreads the financial risk across all individuals in a pool. If, for example, a state agency uses a combination of state taxes, premiums paid by public option enrollees, and federal grants intended to cover federally-eligible Medicaid enrollees to purchase coverage from a private managed care organization, the risk that the managed care organization bears will be spread across all enrollees. If a public option purchaser experiences a catastrophic event requiring expensive care, the funds to provide that care will be drawn from a pool that includes funds intended for federally eligible enrollees. The possibility that public-option purchasers may be sicker, on average, than federally eligible enrollees has prompted some advocates for low-income enrollees to view public option proposals with a wary eye. 189

States could conform to the letter of the law without the need for a waiver if they maintain segregation between state-only funds for buy-in enrollees (partially financed by premium payments) and mixed state and federal funds for federally eligible enrollees. Segregation of funds and prevention of cross-

187 Assemb. B. 374, 2017 Leg., 79th Reg. Sess. (Nev. 2017). (2016)).

188 Id. (citing 42 U.S.C. $§ 1396 \mathrm{a}(25)(\mathrm{G})$ ); id. $§ 1396 \mathrm{~b}(\mathrm{a})(7) ; 42$ C.F.R. $\S 433.15(\mathrm{~b})$

189 Jennifer Lav \& Héctor Hernández-Delgado, State Medicaid Buy-Ins: Implications for Low-Income Enrollees, NAT'L Health L. Program 2 \& 12 n.5 (Feb. 14, 2018), http://www.healthlaw.org/issues/medicaid/state-medicaid-buy-ins-implications-for-lowincome-people [https://perma.cc/MN8M-S2ZT]. 
subsidy would be challenging, but not unprecedented. Several states maintain separate funds to cover abortions for Medicaid enrollees that cannot be financed using federal funds due to the Hyde Amendment. ${ }^{190}$ Many states have adopted a similar approach to segregating payments for abortions covered by plans subsidized by federal funds on the exchanges. ${ }^{191}$

A state seeking an 1115 waiver to circumvent these requirements could easily characterize a public option plan as experimental, given how little is known about the effects of a public option on a state's health care system. Whether it would be "likely to assist in promoting the objectives of [the Medicaid Act]"192 is another matter. Arguably, post-ACA, the objectives of the Medicaid Act include using the Medicaid program as one component of a universal coverage strategy. Others would argue, however, that Medicaid is intended to serve people living in low-income households and provide a buy-in option, which could be exercised by higher-income households, would not serve this purpose. An amenable administration could probably grant such a waiver and survive a legal challenge by traditional Medicaid advocates.

Ultimately, however, the most logical approach to providing a public option in the majority of states would probably not require a waiver. Although public option proposals are described as allowing non-federally eligible residents to buy into the state's Medicaid plan, in the majority of states, there is no single Medicaid plan for residents to buy into. Many states no longer have a single Medicaid benefits package, provider network, reimbursement formula, or claims administration infrastructure for the public option to build on. In states where Medicaid enrollees are already scattered across multiple private and public plans governed by a mix of traditional Medicaid and benchmark standards, placing federally-eligible and buy-in enrollees in a single risk pool and giving them identical benefits would not be feasible even if a waiver were available. In states that have largely privatized Medicaid, the most natural approach would be to develop a public option that relies on the state's infrastructure for Medicaid managed care contracts, but is otherwise separate from Medicaid. The differences between a public option and a standard directpurchase exchange plan in states that have largely privatized Medicaid would probably be minimal. For the plans currently sold on the exchange, the resident purchases coverage from a private insurer subject to state oversight, with or without the help of subsidies paid by the federal government to the insurer. A privatized public option would involve a state contract with a private insurer: for a capitated payment, the insurer would perform some or all of the functions

${ }^{190}$ Id.; Alina Salganicoff et al., The Hyde Amendment and Coverage for Abortion Services, KAISER FAM. FOUND. (Oct. 16, 2017), https://www.kff.org/womens-healthpolicy/perspective/the-hyde-amendment-and-coverage-for-abortion-services/ [https://perma.cc/5SS4-PJY5].

${ }^{191}$ Magda Schaler-Haynes et al., Abortion Coverage and Health Reform: Restrictions and Options for Exchange-Based Insurance Markets, 15 U. PA. J.L. \& Soc. ChAnge 323, 381 (2012).

19242 U.S.C. $\S 1315$ (a) (2012). 
involved in plan design and administration. The resident would pay a specified premium to the state to buy into coverage, but the coverage would otherwise be indistinguishable from private insurance. In this scenario, the impact on Medicaid could be negligible and a waiver may be unnecessary.

\section{Applying ACA Premium Assistance Tax Credits Toward the Purchase of a Public Option}

Regardless of their impact on Medicaid, state buy-in plans could also require an ACA Section 1332 waiver, given that many residents who might purchase public coverage would be eligible for premium assistance tax credits and would be unable to afford the public option without them.

Under ACA Section 1401, PTCs can only be used to purchase a qualified health plan (QHP) on an exchange. This provision could be waived by HHS pursuant to Section $1332 .{ }^{193}$ Alternatively, a state could attempt to design its public option plan to satisfy the statutory requirements for QHPs set forth in Section 1301, obviating the need for a waiver. Jennifer Lav and Héctor Hernández-Delgado, writing for the National Health Law Program, state rather conclusively that "Medicaid, by definition, is not a QHP" and thus buy-in public option plans would require a 1332 waiver. ${ }^{194}$ A report for the State Health \& Value Strategies initiative, authored by Patricia Boozang, Chiquita BrooksLaSure, and Ashley Traube of Manatt Health reached a contrary conclusion, determining that "[i]t is possible to structure the state-sponsored product buy-in option without the need for 1332 waiver authority, which states might want to seriously consider given the administrative burden of applying for a 1332 waiver and the uncertainty of approval." 195 Given how crucial PTCs would be to the success of a state-level public option, how many states are interested in pursuing a public option, and how unlikely the current administration is to grant a 1332 waiver to allow it, the question merits further consideration.

ACA Section 1301 sets forth the requirements for QHPs, specifying that they must (1) be approved by the exchange, (2) offer the essential health benefit (EHB) package set forth in Section 1302(a), and (3) be offered by a health insurance issuer that is (4) "licensed and in good standing to offer health insurance coverage in [the state in which it offers coverage on the exchange]." 196 Additionally, the health insurance issuer must (5) agree "to offer at least one qualified health plan in the silver level and at least one plan in the gold level" on the exchange, (6) refrain from setting differential premiums depending on whether the plan is offered on the exchange or "offered directly from the issuer or through an agent," and (7) comply with HHS regulations

193 Patient Protection and Affordable Care Act, Pub. L. No. 111-148, § 1332, 124 Stat. 120 (2010).

${ }^{194}$ Lav \& Hernández-Delgado, supra note 189, at 12 n.5.

195 See BoOZANG ET AL.,, supra note 169, at 3.

${ }^{196}$ Patient Protection and Affordable Care Act, Pub. L. No. 111-148, § 1301, 124 Stat. 120 (2010). 
promulgated under Section 1311(d) and any other requirements established by the exchange. ${ }^{197}$

The first requirement is easily dispensed with in states that run their own exchanges. State-run exchanges have flexibility to approve a state Medicaid plan as a QHP, assuming that the other six requirements can be satisfied. With respect to the second requirement, Lav and Hernández-Delgado draw a distinction between exchange plans, which must offer coverage that satisfies the ACA's EHB requirements, and Medicaid plans, which must offer coverage specified in the Medicaid statute. ${ }^{198}$ But that distinction belies the flexibility states have to enroll many Medicaid recipients in alternative benefit plans. As described above, the ACA imposed the same baseline requirements on Medicaid alternative benefit plans as QHPs sold on the exchange: the EHB package. ${ }^{199}$ Medicaid plans typically offer more comprehensive coverage than QHPs, not less. ${ }^{200}$ Moreover, pursuant to a 2012 HHS regulation, states have flexibility to define the EHB package by selecting a benchmark plan from among specified options, ${ }^{201}$ giving them considerable authority to align their public option plan with the EHB requirements.

Would a Medicaid buy-in plan be "offered by a health insurance issuer"? And could it be "licensed" by the state? Whether the remaining requirements of Section 1301 are met could turn on the meaning of the term "offered." In most states, most Medicaid enrollees are covered by private health insurance companies that contract with the state. ${ }^{202}$ Is a privately administered Medicaid managed care plan "offered" by the private insurance company even when it is operated pursuant to a contract with the state? Or is such a plan "offered" by the state exclusively? What about Vermont's Medicaid managed care plan, which is fully state run? Is Vermont's publicly administered managed care plan a "health insurance issuer" if it is purchased by enrollees who pay premiums on the exchange? With respect to the fifth requirement of Section 1301, one solution would be for the state to contract with a private insurer that also offers gold and silver plans on the exchange. Another option would be to develop two public option plans - one with gold-level cost sharing at a lower premium and the other with silver-level cost sharing at a higher premium. Regarding the sixth requirement, there is an open question as to whether the state would be permitted to offer a no-premium Medicaid plan to federally eligible enrollees (as required

19742 U.S.C. $\S 18021$ (2012).

198 Lav \& Hernández-Delgado, supra note 194, at 2-3.

${ }^{199}$ See infra text accompanying note 74 .

200 David Lipschutz et al., Comparison of Consumer Protections in Three Health Insurance Markets: Medicare Advantage, Qualified Health Plans and Medicaid Managed Care Organizations, KAISER FAM. FOUND. (Mar. 19, 2015), https://www.kff.org/reportsection/comparison-of-consumer-protections-in-three-health-insurance-marketscomparison-of-specific-areas-of-consumer-protections/ [https://perma.cc/LR8A-2G3V].

20145 C.F.R. $\$ 156.100$ (2018).

${ }^{202}$ Lipschutz et al., supra note 200. 
under the Medicaid statute absent a waiver) while offering a buy-in Medicaid plan for sale on the exchange.

These questions are unsettled. If a state does adopt a Medicaid buy-in plan without obtaining waivers from HHS, it could face a legal challenge. Even if the state carefully tailored its public option plan to comply with federal Medicaid law and the ACA's requirements in the absence of waivers, the prospect of expensive litigation may be enough to chill progressive enthusiasm.

To address these uncertainties, progressive Democrats, including many seen as likely contenders for the 2020 presidential nomination, have introduced federal legislation to facilitate Medicaid buy-in plans at the state level. ${ }^{203}$ At least one conservative Republican countered with a proposal to prohibit states from using federal funds to support single-payer health care. ${ }^{204}$ The growing politicization of the public option strategy could make state lawmakers reluctant to proceed. On the other hand, progressive Democrats in some states may find there are gains to be made in publicly taking a stand in favor of more radical health reform strategies, even as advocates remain uncertain as to the precise shape such strategies may take.

\section{Going Further: State-Level Single-Payer Health CARE}

This Article argues that states can and should honor international legal norms regarding the right to health by adopting single-payer health care financing at the state level. Under a single-payer system, health care coverage for a defined bundle of essential health benefits would be publicly financed. ${ }^{205}$ The health care delivery system - made up of hospitals, physician groups, longterm care providers, etc. - would retain the mix of mostly private providers and some publicly administered hospitals that we have today. Consumers would probably remain free to purchase supplemental coverage from private insurers, although in some cases, other countries have prohibited private insurance coverage that directly competes with the single-payer plan by covering the same bundle of benefits. ${ }^{206}$

Globally, several countries provide publicly financed, privately delivered universal health care. In some, the system is financed and operates entirely at the national level. Many of the most prominent examples, however, are financed

${ }^{203}$ State Public Option Act, S. 2001, 115th Cong. (2017).

204 See Mallory Shelbourne, GOP Senator Eyes Ban on States' Single Payer Systems, THE HILL (Sept. 19, 2017), http://thehill.com/policy/healthcare/351344-gop-senator-eyesban-on-states-single-payer-systems [https://perma.cc/9QUN-EBLK] (quoting Republican Senator John Kennedy of Louisiana regarding his proposal to amend the Graham-Cassidy reform bill to add a provision prohibiting states from using federal funds to support singlepayer health care).

205 Jonathan Oberlander, The Virtues and Vices of Single-Payer Healthcare, 374 NEW ENG. J. MED. 1401, 1401 (2016).

${ }^{206}$ In Canada, the Supreme Court struck down a prohibition on private insurance. Chaoulli v. Attorney Gen. of Que., [2005] 1 S.C.R. 791, 805, 810 (Can.). 
and administered jointly by the national government and subsidiary governments (such as states, provinces, or districts). ${ }^{207}$ Single-payer systems are typically financed through payroll taxes, income taxes, an earmarked health care tax, or a combination of the three. ${ }^{208}$ These taxes are typically progressive, with the tax rate rising at higher incomes. ${ }^{209}$ Thus, shifting from our current system (in which the majority of individuals are covered by employer-based insurance subsidized through tax exemptions that disproportionately benefit higherincome households) to a single-payer system financed primarily through progressive taxes would redistribute the burden of paying for health care coverage from lower- to higher-income households.

Single-payer health care financing was never seriously considered in the debates that culminated in the ACA. ${ }^{210}$ Following the 2016 election, in which Senator Bernie Sanders expressed strong support for Medicare for All, the idea gained traction among Democratic legislators and contenders for the 2020 presidential nomination. ${ }^{211}$ It still faces many political obstacles, ${ }^{212}$ however, and lawmakers are often vague on the details of how it would work. ${ }^{213}$

Concerns about the percentage of the population that remains uninsured, high premiums and out-of-pocket costs for those who are insured, and the disparate impact of these gaps on people of color have prompted policymakers in several states to consider single-payer health care financing. ${ }^{214}$ In 2011, Vermont's legislature passed and Governor Peter Shumlin signed legislation to

207 See generally Jacalyn Duffin, The Impact of Single-Payer Health Care on Physician Income in Canada, 1850-2005, 101 AM. J. PUB. HeALTH 1198 (2011) (describing the Canadian health care system's inception in Saskatchewan and its gradual expansion over the latter twentieth century).

${ }^{208}$ See generally Jost, supra note 8 (discussing the financing of single-payer health care systems outside the United States).

${ }^{209}$ Id.

210 See McGill \& MacNaughton, supra note 167, at 659 ("“A]lthough a CBS poll taken in 2009, around the time the PPACA was drafted, showed 59 percent of U.S. residents supported government sponsored health insurance, the architects of health care reform never considered a single-payer health care system to be a viable option.").

211 Medicare for All, FRIENDS OF BERNIE SANDERS, https://berniesanders.com/medicare forall/ [https://perma.cc/XD94-MM9J]); Ed Clendaniel, How Medicare for All Could Sway Voters in 2020, MERCURY NEWS (July 21, 2018), https://www.mercurynews.com/2018/07/ 21/editorial-medicare-for-all/ [https://perma.cc/M8HE-M8PW].

212 Oberlander, supra note 205, at 1402-03 ("Medicare for All, which aims to constrain health care spending, faces intense opposition from insurers, the medical care industry, and much of organized medicine .... Although Americans would save money by not paying premiums to private insurers, the politics of moving immense levels of health care spending visibly into the federal budget are daunting, given the prevailing antitax sentiment .... Then there are the familiar institutional barriers to major reform within U.S. government, including the necessity of securing a supermajority of 60 votes in the Senate to overcome a filibuster. In short, single payer has no realistic path to enactment in the foreseeable future.").

${ }^{213}$ See Scott, supra note 168.

214 See, e.g., WHITE ET AL., supra note 92, at ix. 
implement a single-payer system over a six-year period. ${ }^{215}$ The implementation plan would have involved maximizing Medicaid eligibility under federal law ${ }^{216}$ and then seeking waivers that would allow the state to redirect federal Medicaid and ACA funding toward the new state single-payer program. ${ }^{217}$ Proponents initially hoped that a significant state tax hike would not be necessary. ${ }^{218}$ But by 2014 , it became clear that the state would have to adopt a new income tax of around $9.5 \%$ and an $11.5 \%$ payroll tax on employers. ${ }^{219}$ The payroll tax and other strategies for bringing people previously covered by employer-based health plans into the state single-payer plan triggered concerns about ERISA preemption. Thus, Vermont determined that it would also have to navigate all of the legal obstacles applicable to the strategies discussed in Parts I and II: ERISA preemption, Medicaid Section 1115 waivers, and ACA Section 1332 waivers. In 2014, Shumlin reversed his position and terminated implementation, citing "limitations of state-based financing-limitations of federal law, limitations of our tax capacity, and sensitivity of our economy."220

Health policy wonks often point to the shadow that failed health reform efforts can cast - rendering politicians reluctant to return to the issue after a bruising fight. In spite of Vermont's failure, however, lawmakers in Vermont and other states continue to explore single-payer proposals. In 2017, California legislators introduced similar single payer legislation to cover all Californians, including about two million undocumented immigrants. ${ }^{221}$ The bill passed out of committee but was shelved by the California Speaker of the Assembly Anthony Rendon on the grounds that it failed to address financing and cost controls. ${ }^{222}$ One report cited the need for a $15 \%$ payroll tax increase to fund the single payer system, even assuming California would receive HHS approval to divert all federal funds from Medicaid and private exchange subsidies toward

215 William C. Hsiao et al., What Other States Can Learn from Vermont's Bold Experiment; Embracing a Single-Payer Health Care Financing System, 30 Health AfF. 1232, 1232 (2011).

216 The initial financing plan was to increase the state's Medicaid spending by $3 \%$ each year to maximize optional federal expansions. See John E. McDonough, The Demise of Vermont's Single-Payer Plan, 372 New ENG. J. Med. 1584 (2015).

217 Id.

218 Id.

219 Id.

220 State of Vermont, Green Mountain Care: A Comprehensive Model for BuILDing VERMONT's UnIVERSAL HEALTH CARE SYSTEM (2014) http://hcr.vermont.gov/ sites/hcr/files/pdfs/GMC\%20FINAL\%20REPORT\%20123014.pdf [https://perma.cc/KS2T3Y3D] [hereinafter GMC 2014 REPORT].

221 Healthy California Act, S.B. 562, 2017 Leg., Reg. Sess. (Cal. 2017).

222 Katy Murphy \& Tracy Seipel, Single-Payer Health Care Put on Hold in California as Leader Calls Bill “Woefully Incomplete," MERCURY News (June 24, 2017), https://www.mercurynews.com/2017/06/23/breaking-single-payer-health-care-put-on-holdin-california-as-leader-calls-legislation-woefully-incomplete/ [https://perma.cc/6LQTN4ED]. 
the single payer system. ${ }^{223}$ A similar proposal has repeatedly passed the New York Assembly - in 2015, 2016, 2017, and 2018 - but New York has a bicameral legislature and the senate has refused to put the measure to a vote. ${ }^{224}$ Oregon's legislature is exploring a similar proposal. ${ }^{225}$ Many commentators see the 2018 elections as a key test of support for candidates who support Medicarefor-All and Medicaid-for-All proposals, ${ }^{226}$ even as Democratic party leadership warned candidates that specifically referring to "single-payer" plans was fraught with political risk. ${ }^{227}$

To say that a state-level single-payer system is more politically feasible than a federal single-payer system is not to say that a state-level plan is in any way easy or likely. The political environment may be more favorable for singlepayer proposals at the state level, but state governments seeking to adopt a single-payer plan face particular legal hurdles not applicable to the federal government. Unlike the federal legislature, nearly all state legislatures operate under some form of balanced budget requirement, at least with respect to the state's general fund. ${ }^{228}$ Federal income taxes crowd out state and local taxes, a constraint that is exacerbated by 2018 legislation that eliminates the state income tax deduction. ${ }^{229}$ As noted above, the contours of ERISA preemption of state-level health reform remain deeply uncertain. ${ }^{230}$ While statutory waivers provide avenues for states to repurpose federal funds to support a state-level single-payer plan, the HHS Secretary is given considerable discretion to deny state waiver applications, even where statutory criteria are met. ${ }^{231}$ The dependence of waivers on negotiations between state and federal officials

${ }^{223}$ See Angela Hart, Raise Taxes or Ration Health Care? Why Single-Payer Won't Work in California. Yet, SACRAMENTO BEE (Mar. 13, 2018), https://www.sacbee.com/news/ politics-government/capitol-alert/article201541734.html [https://perma.cc/34RM-JEQF].

224 Assemb. B. A04738, 2017 Leg., Reg. Sess. (N.Y. 2017).

225 See WHITE ET AL., supra note 92, at 1.

${ }^{226}$ Dylan Scott, Single-Payer's Big Test: Can Medicare-for-All Win in Competitive House Districts?, Vox (June 1, 2018), https://www.vox.com/policy-and-politics/2018/6/1/ 17378840/california-democratic-primary-2018-medicare-for-all [https://perma.cc/FB2YASTT].

227 Jennifer Haberkorn, The Two Words You Can't Say in a Democratic Ad, Politico (June 8, 2018), https://www.politico.com/story/2018/06/08/democratic-single-payer-healthcare-ads-609066 [https://perma.cc/22NF-42JZ].

228 See generally NAT'L CONF. OF ST. Legislatures, NCSL Fiscal Brief: State BALANCED Budget PROVISIONS (Oct. 2010), http://www.ncsl.org/documents/fiscal/State BalancedBudgetProvisions2010.pdf [https://perma.cc/MM79-NU4C] (surveying state balanced budget requirements).

${ }^{229}$ Nat'l Fed'n of Indep. Bus. v. Sebelius, 567 U.S. 519, 680 n.13 (2012) (Scalia, Kennedy, Thomas, \& Alito, JJ., dissenting); Andrea Louise Campbell, The Republican Tax Bill Will Make It Harder for States and Cities to Pay Their Bills, WASH. Post (Dec. 21, 2017), https://www.washingtonpost.com/news/monkey-cage/wp/2017/12/21/the-republican -tax-bill-will-make-it-harder-for-states-and-cities-to-pay-their-bills/ [https://perma.cc/8LF 6-2S9F].

230 Bagley, supra note 118 , at 15.

23142 U.S.C. § 1315(a) (2012). 
influenced by the shifting winds of political change and the possibility of legal challenges from industry groups with a great deal of money at stake inject considerable uncertainty into state policymaking. In spite of these obstacles, a state-level single-payer playbook is beginning to take shape. It would require states to maximize federal funds under existing programs, repurpose those funds to finance single-payer coverage, and develop new state revenue streams while avoiding ERISA preemption.

\section{A. Repurposing Existing Federal Funds to Finance a State-Level Single-Payer Plan}

The starting point for single-payer financing at the state level is to repurpose state and federal funds already committed to covering the state's residents. Redirecting existing state funds to a single-payer system is relatively simple, but federal health care funds come with restrictions. At first blush, it may seem that Republican proposals to block grant existing federal assistance would be a boon to states seeking additional flexibility to create a single payer system. The flexibility of a block grant would indeed be helpful, but current proposals are aimed at cutting federal health spending over time, without adopting any strategies to cut overall health care costs. ${ }^{232}$ Their primary goal is to shift costs from the federal government to the states, hospitals, and families, not to give states flexibility to achieve universal coverage with full federal support. ${ }^{233}$ In the absence of a block grant that keeps pace with health care costs, states must exploit flexibilities within existing health care programs.

Nationwide in $2016,45 \%$ of health care expenditures were paid for by governments at the federal, state, and local levels. ${ }^{234}$ Medicare accounts for $20 \%$ of all U.S. health care spending; Medicaid accounts for $17 \% .{ }^{235}$ The remaining public funds go to the Children's Health Insurance Program ACA subsidies, and premium contributions to cover public employees. ${ }^{236}$ Government health care spending per person in the United States is comparable to per-capita spending from all sources in Canada, the United Kingdom, and many other countries. ${ }^{237}$

232 See Block Grants: A Bad Idea for Medicaid, FAMILIES USA (Apr. 2016), http://familiesusa.org/sites/default/files/product_documents/MCD_Block_Grant_Factsheet. pdf [https://perma.cc/3JQ9-CRVM].

233 Id.

234 Ctrs. For Medicare \& Medicaid Servs., NAtional Health Expenditures 2016 HigHLIGHTS 3 (2016), https://www.cms.gov/Research-Statistics-Data-and-Systems/ Statistics-Trends-and-Reports/NationalHealthExpendData/Downloads/highlights.pdf [https://perma.cc/3VD7-H887] [hereinafter CMS HIGHLIGHTS].

235 Id.

${ }^{236}$ Cong. Budget OfF., The 2018 Long-Term Budget Outlook 17 (June 2018), https://www.cbo.gov/system/files?file=2018-06/53919-2018ltbo.pdf [https://perma.cc/D65S-4UU5].

237 At $45 \%$ of all health care expenditures in the United States, government expenditures amount to $\$ 4,656$ per person. $I d$. This is comparable to per capita expenditures from all 
But health care prices - the fees paid to physicians, hospitals, and pharmaceutical companies - are far higher here than elsewhere. ${ }^{238}$ And even if existing public expenditures were sufficient to provide universal health care access for all residents, lawmakers seeking to redirect funds to a single government social insurance program face political obstacles at the federal level and legal obstacles at the state level. These legal obstacles can be overcome by states with careful planning and the approval of a sympathetic presidential Administration.

\section{Complying with Federal Medicaid Law}

To ensure that federally eligible Medicaid enrollees receive the benefits to which they are entitled under federal law, a state single-payer plan must either (1) provide the most generous coverage mandated by federal law for any group of enrollees to all enrollees or (2) provide distinct benefit packages to various populations depending on their status under federal law. As described above, however, Medicaid benefit packages may vary from plan to plan within a state, depending on enrollees' status under federal and state law, various waivers a state might have already obtained, the specific terms negotiated between the state Medicaid agency and private companies, and various matters left to the discretion of public and private decision-makers. ${ }^{239}$ The Medicaid benefit packages to which at least some enrollees are entitled under federal law extend well beyond what private insurance typically covers. ${ }^{240}$ Other benefit packages provided by states to Medicaid enrollees are indistinguishable from the private insurance plans sold on the state's exchange. ${ }^{241}$ Realistically, single-payer plan cannot — and probably should not — adopt a uniform approach to benefits for all enrollees.

Existing state single-payer proposals have generally specified that all residents who enroll in the plan will, for the most part, be entitled to the coverage currently offered to Medicaid enrollees, while continuing to distinguish among groups of residents by offering certain benefits only to federally-eligible enrollees. Under Oregon's single-payer proposal, for example, all residents

sources in Canada $(\$ 4,752)$ and the United Kingdom $(\$ 4,192)$; see Sawyer \& Cox, supra note 1 .

${ }^{238}$ See, e.g., Sarah Kliff \& Soo Oh, America's Health Care Prices Are Out of Control. These 11 Charts Prove It., Vox (May 10, 2018), https://www.vox.com/a/health-prices [https://perma.cc/8R8L-DSCD] (analyzing data from the International Federation of Health Plans 2016 Report).

239 See supra Part II.

24026 U.S.C. $\S 36 \mathrm{~B}(\mathrm{~b})(2012)$; see also Hannah Katch, Medicaid Works: Millions Benefit from Medicaid's Effective, Efficient Coverage, Ctr. Budget \& Pol'y Priorities (June 2, 2017), https://www.cbpp.org/research/health/medicaid-works-millions-benefit-frommedicaids-effective-efficient-coverage [https://perma.cc/CEJ5-CMRW].

${ }^{241}$ See What the Actuarial Values in the Affordable Care Act Mean, KAISER FAM. FouND. (Apr. 2011), https://kaiserfamilyfoundation.files.wordpress.com/2013/01/8177.pdf [https://perma.cc/FK5H-MRD5]; Katch, supra note 240. 
under age 21 would be covered for early and periodic screening, diagnosis, and treatment services, regardless of their status under federal law, but other benefits would be limited to federally eligible enrollees. ${ }^{242}$ Vermont's single-payer plan would have been facilitated by the fact that the state does not rely on private coverage for any of its Medicaid enrollees. Green Mountain Care, the state's publicly administered Medicaid managed care plan, would have been opened up to all residents. ${ }^{243}$ Those who are federally eligible for Medicaid coverage would have continued to receive coverage mandated by federal law, ${ }^{244}$ while other enrollees could receive more limited benefits. ${ }^{245}$

Even if a state's single-payer plan carefully ensures that all enrollees receive at least the minimum benefits to which they are entitled under federal law, it would still require an 1115 waiver if federal Medicaid funds are in any way mingled with funds used to cover people who are not eligible for Medicaid. ${ }^{246}$ Separation of risk pools and segregation of funds would be difficult, but not impossible, as described above in the section on public option plans, but segregated risk pools could undermine some of the purposes that a single-payer plan might serve, as discussed in Part IV, below.

A state single-payer waiver application would have to satisfy all of the requirements for Section 1115 discussed in Part I. Like public-option plans, a single-payer plan would trigger debate regarding its relation to the purpose of the Medicaid Act. Additionally, negotiations between the state and HHS over the appropriate baseline for judging budget neutrality would be crucial. Perhaps most troubling, a Section 1115 waiver could require periodic reauthorization, ${ }^{247}$ putting a state's entire single-payer system at the mercy of not just one presidential administration, but potentially many.

\section{Complying with the ACA}

Unlike public-option proposals, single-payer proposals do not typically contemplate that residents would purchase their coverage on the state's health insurance exchange. Redirecting ACA premium assistance tax credits to help fund a state single-payer plan would thus require a Section 1332 waiver regardless of how ACA requirements for qualified health plans sold on the exchange are interpreted.

242 WHITE ET AL., supra note 92, at ix. Oregon's plan would also provide EPSDT coverage for all residents under age 21 . Id.

243 Act 48, 2011 V.T. H.202 § 2(a)(1) (2011); id. § 2(a)(5).

${ }^{244}$ Id. $\S 1825$ (b)(1)(A) ("For individuals eligible for Medicaid or CHIP, the benefit package shall include the benefits required by federal law, as well as any additional benefits provided as part of the Green Mountain Care benefit package.").

245 Id

24642 U.S.C. $\S 1315$ (2012).

24742 U.S.C. $\$ 1315(\mathrm{e})-(\mathrm{f})$. 
Vermont officials initially anticipated that federal funds would be available from an ACA Section 1332 waiver pass-through. ${ }^{248}$ In the final report on financing options, however, officials noted that "estimates of available federal ACA funds were downgraded significantly as we entered into actual discussions with the federal government about such a waiver," 249 implying that federal officials were discouraging about the likelihood that the Obama Administration would grant a 1332 waiver to support Vermont's single-payer plan.

If a president more amenable to state-level single-payer health care were to be elected in 2020 or beyond, the use of ACA funds passed through to the state pursuant to a waiver would impose coverage requirements applicable to at least some enrollees. Given the 2016 harmonization of federal requirements applicable to privatized Medicaid plans and qualified health plans subsidized by the ACA, however, these requirements are unlikely to be insurmountable. There are a few areas where ACA requirements would limit state flexibility, however. For example, the Vermont plan noted that, in addition to covering "primary, preventive, and chronic care, as well as urgent care and hospital services," Vermont legislators determined that "GMC would cover dental and vision . . u up to age 21 , as required by the [ACA]." 250

\section{Exploring Options Under Medicare}

The strategies discussed in Parts I and II do not involve tinkering with Medicare, the federal program that provides coverage for most U.S. citizens and permanent residents over age sixty-five and people with qualifying disabilities, regardless of age. States typically have no role in the financing or administration of Medicare. Thus, Medicare does not include the kinds of broad waiver provisions that would make it possible to divert federal funding under Medicaid and the ACA private insurance to a state single-payer plan.

There is no clear path for directing Medicare funds to a state single-payer plan that covers residents who are eligible for Medicare. Vermont officials initially considered relying on an unspecified combination of Medicare provisions "to align the Medicare payment and delivery requirements with Medicaid."251 Under Section 1395b-1, the HHS Secretary may engage in demonstration projects, including through grants or contracts awarded to public agencies, to experiment with new Medicare payment and reimbursement systems. ${ }^{252}$ But Medicare demonstration projects tend to focus on particular functions and have only rarely been led by states. Through a waiver that has now been codified into the Medicare statute, Maryland created the first system

248 See GMC 2014 REPORT, supra note 220, at 4.

249 Id.

250 Id. at 3 .

${ }^{251}$ HSIAO ET AL., supra note 8, at 15 (citing 42 U.S.C. § 1315a; 42 U.S.C. § 1395b-1; 42 U.S.C. $\S 1395 \mathrm{kk}-1$; and 42 U.S.C. $§ 1395 \mathrm{jjj}$ as possible avenues to a waiver facilitating coverage of Medicare beneficiaries under Vermont's single-payer plan).

25242 U.S.C. $\S 1395$ b-1 (2012). 
for setting hospital rates and later moved to a system of global budgets for hospitals. ${ }^{253}$ The ACA, in a provision establishing payment and delivery models for testing, allowed states to test all-payer payment reforms such as Maryland's. ${ }^{254}$ State single-payer advocates sometimes point to the Maryland example, but have failed to articulate how a single-payer plan might be crafted as a Medicare demonstration project. ${ }^{255}$ Under Section $1395 \mathrm{kk}$, the HHS Secretary may hire contractors to administer benefits under certain conditions. ${ }^{256}$ A state agency could qualify as a Medicare administrative contractor, enabling it to process Medicare claims using the same system that processes claims made under the state's single payer plan. ${ }^{257}$ But acting as a Medicare contractor would provide limited funds and would not give the state control over the formulas used to calculate reimbursement rates. None of these provisions is a clear fit for incorporating Medicare enrollees (and funds) into a state-level single-payer plan. Vermont officials eventually determined that residents eligible for Medicare would not participate in the state's single-payer plan. 258

In theory, a state could attempt to qualify its state single-payer plan as an alternative coverage option (subsidized by federal funds) for Medicare enrollees under Medicare Part C, also known as Medicare Advantage. ${ }^{259}$ Medicare Advantage was designed to offer people eligible for Medicare the option of enrolling in subsidized private plans. ${ }^{260}$ These plans offer more comprehensive financial protection than traditional Medicare, which features such onerous deductibles and co-pays that most deem supplemental coverage necessary. ${ }^{261}$ Means-tested premiums have long been a feature of traditional Medicare. Under Part C, enrollees pay their premium to a private health plan, which also receives a payment from the federal government on a per-enrollee basis. ${ }^{262}$ Ultimately, however, the requirements applicable to Medicare Advantage plans may not be practical for a state single-payer plan to satisfy. ${ }^{263}$ Moreover, offering coverage

253 Maryland All-Payer Model, CTRS. FOR MedicARE \& MEdICAID SERvs., https://innovation.cms.gov/initiatives/Maryland-All-Payer-Model/ [https://perma.cc/82MDC4T9].

25442 U.S.C. $\S 1315 \mathrm{a}(\mathrm{b})(2)(\mathrm{B})(\mathrm{xi})$.

255 See New York Health Act FAQ, CAMPAIGN FOR N.Y. HEALTH, https://d3n8a8pro7vhmx.cloudfront.net/pnhpnymetro/pages/4148/attachments/original/152 9527348/Federal Waivers FAQ.pdf?1529527348 [https://perma.cc/Y3WD-WNX9] ("The Maryland waiver shows that significant changes in payment methods in a state have been treated by CMS as compatible with the intent of the original Medicare legislation.").

25642 U.S.C. $§ 1395 \mathrm{kk}-1$.

257 See New York Health Act FAQ, supra note 255, at 4.

258 See GMC 2014 REPORT, supra note 220, at 3.

259 See New York Health Act FAQ, supra note 255, at 2.

$260 \mathrm{Id}$. at $2-3$.

261 Id.

262 See CMS HighLIGHTS, supra note 234, at 3; Buck, supra note 50, at 111 n.9.

263 See HSIAO ET AL., supra note 8, at 15 n.8. 
under Medicare Advantage requires entering into a contract with CMS. ${ }^{264} \mathrm{~A}$ hostile Administration could easily decline to contract with a state-level singlepayer plan, even if that plan were administered through state contracts with private insurance companies. Alternatively, an amenable Administration could draft new contracting guidelines that clarify the eligibility of state single-payer plans and, of course, Congress could always add a waiver provision to the Medicare statute to allow Medicare funds to be passed through to states via Medicare Part $\mathrm{C}$ or an entirely new mechanism.

\section{B. Developing New State Revenues}

Current government health care expenditures in the United States may be comparable to those of other countries that operate single-payer health systems, ${ }^{265}$ but because prices are much higher here, new revenue streams would certainly be required to finance single-payer health care at the state or federal level. States interested in single-payer health care need considerable financing above and beyond what repurposed federal funds could cover. Most state proposals point to the necessity of new payroll and income taxes. ${ }^{266}$ Payroll taxes paid by employers raise the specter of ERISA preemption. Both payroll and income taxes would also need to be carefully designed to ensure that residents and employers are not subjected to additional federal tax burdens.

\section{Navigating ERISA Preemption}

Private employers pay for about $20 \%$ of health care expenditures in the United States. ${ }^{267}$ Employer payroll taxes are thus an obvious strategy for redirecting employers' current expenditures on health coverage for their employees to a state-financed single-payer plan. Additionally, to achieve the purchasing power of a true single-payer system, the state must bring the large proportion of residents currently covered by private, employer-based insurance into the publicly financed system. The state could do so by (1) requiring employers to purchase public coverage for their employees, (2) imposing a payroll tax to help fund public coverage and prohibiting employers from offering competing coverage, or (3) imposing a payroll tax to help fund public coverage without prohibiting employers from offering competing coverage. Under ERISA, states are almost certainly barred from adopting the first and second options, at least with respect to employers who self-insure. State provisions requiring or prohibiting employers from offering health coverage relates to employment benefits and thus would fall under ERISA's preemption

${ }^{264}$ Ctrs. For Medicare \& Medicaid Servis., Medicare Managed Care Manual Chapter 11 Medicare AdVANTAge Application Procedures and Contract Requirements, Medicare Managed Care Manual, § 20.1 (2007).

265 See Sawyer \& Cox, supra note1.

266 See GMC 2014 REPORT, supra note 220, at 34.

267 See CMS HigHLIGHTS, supra note 234, at 3. 
clause. With respect to fully insured employer benefits, a mandate or prohibition could potentially be saved from preemption as a regulation of insurance, but no such savings argument would be available with respect to self-insuring employers.

Vermont officials pursued the third option. In addition to the repurposed state and federal funds outlined above, their single-payer plan would have been financed through a combination an $11.5 \%$ payroll tax and "income-based family contributions" 268 calculated on a sliding scale from $0 \%-9.5 \%$ of household income. ${ }^{269}$ Because employers would have been subject to the payroll tax regardless of what benefits they offered and because their employees would have been eligible for the single-payer plan, officials assumed that $70 \%-100 \%$ of Vermonters currently covered in the small-group employment-based market and $50 \%-100 \%$ of those in large-group employment-based plans would have migrated to the single-payer plan as their primary source of coverage. ${ }^{270}$

Even if employers are not required to purchase public coverage or prohibited from purchasing private coverage for their employees, imposing a new payroll tax on employers to fund public coverage raises the possibility of ERISA preemption. Whether a single-payer payroll tax would be preempted by ERISA is not at all clear, though leading experts have opined that it would not. 271

The payroll tax envisioned by Vermont lawmakers would apply regardless of any choice an employer makes regarding health benefits. Its indirect regulatory impact would thus be less clear than for a pay-or-play mandate that

268 See GMC 2014 REPORT, supra note 220, at 3.

${ }^{269} \mathrm{Id}$. at 5 .

${ }^{270}$ Nolan Langweil, Act 48 Report Overviews, U. Mass. Med. SCH., Ctr. HeAlth L. ECON. \& WAKLEY CONSULTING GROUP, LLC.1 (Jan. 2014), https://legislature.vermont.gov /assets/Documents/2016/WorkGroups/Senate $\% 20$ Health $\% 20$ and $\% 20$ Welfare/Health\%20C are $\% 20$ Reform/W Nolan\%20Langweil UMASS\%20\%20Wakely\%20Study $\% 20$ (Act $\% 20$ 48\%20of\%202011) 1-16-2015.pdf [https://perma.cc/ZVG6-35TR].

271 See, e.g., Janet L. Kaminski, ERISA Preemption and State Health Care Reform, CT GEN. ASSEMB. (Feb. 9, 2007), https://www.cga.ct.gov/2007/rpt/2007-R-0131.htm [https://perma.cc/56L3-MZHZ]; HSIAO ET AL., supra note 8, at 9-10; Patricia A. Butler, ERISA Preemption Manual for State Health Policy Makers, NAT'L ACAD. ST. HEALTH POL'Y 17 (Jan. 2000), http://www.statecoverage.org/files/ERISA\%20Preemption\%20Manual\% 20for\%20State\%20Health\%20Policymakers.pdf [https://perma.cc/EHE6-5UXA]. But see Patricia A. Butler, What We Can Learn About Federal ERISA Law from Maryland's Court Decision, WISC. FAM. IMPACT SEMINARS 5 (2014), http://wisfamilyimpact.org/wpcontent/uploads/2014/10/s_wifis24c01.pdf [https://perma.cc/KA88-KRSA] ("ERISA preemptions become more complicated if a universal public program is financed by an employer payroll tax. Conceivably, multistate employers might feel they are being forced to pay twice - their own health coverage costs as well as the payroll tax. For this reason, a single-payer plan funded by income tax (or an employee-only payroll tax) might be easier to defend from an ERISA challenge than an employer-paid payroll tax."); New York Health Act FAQ: The “ERISA Problem," N.Y. HEALTH, https://d3n8a8pro7vhmx.cloudfront.net/pnhp nymetro/pages/4148/attachments/original/1529527207/ERISA_FAQ.pdf?1529527207 [https://perma.cc/Y3WD-WNX9]. 
applies only if the employer declines to provide benefits. The state could argue that a payroll tax is simply a financing mechanism. The fact that the revenues would be used to provide health care coverage to all state residents could be construed as incidental to the fundraising component of the tax. Additionally, the carrot-only approach, whereby the state offers public coverage to all residents regardless of whether employer-based coverage is available to them could be seen as very different from the stick of a pay-or-play mandate.

On the other hand, employers wishing to challenge the payroll tax could argue that its impact on ERISA plans must be considered in light of legislators' intent to redirect employer health care spending from the private market to public financing, while also broadening the state's risk pool by encouraging employers to drop coverage. State lawmakers considering single-payer health care should probably begin by focusing on the U.S. Supreme Court opinion that is closest to being on-point. In New York State Conference of Blue Cross \& Blue Shield Plans v. Travelers Insurance Co., the Supreme Court held that a New York law requiring hospitals to collect surcharges from patients covered by any commercial insurer other than a Blue Cross/Blue Shield plan was permissible under ERISA. ${ }^{272}$ In the words of the Court: "Although there is no evidence that the surcharges will drive every health insurance consumer to the Blues, they do make the Blues more attractive (or less unattractive) as insurance alternatives and thus have an indirect economic effect on choices made by insurance buyers, including ERISA plans." 273 Because this "indirect economic influence ... does not bind plan administrators to any particular choice and thus function as a regulation of an ERISA plan itself; commercial insurers and HMO's may still offer more attractive packages than the Blues." 274 Perhaps most concerning for a single-payer state, the Court cautioned in dicta that "even in the absence of mandated coverage there might be a point at which an exorbitant tax leaving consumers with a Hobson's choice would be treated as imposing a substantive mandate."275

Would a hefty payroll tax combined with the availability of public coverage from the state "bind plan administrators to [a] particular choice"? Would it amount to "a substantive mandate" - one that prohibits employers from offering health benefits rather than mandating that they must do so? The federal courts' analysis could echo the Supreme Court's analysis of whether the ACA's attempt to impose a mandatory Medicaid expansion on states was impermissibly coercive. Just as the ACA's drafters clearly contemplated that all, or nearly all, states would choose to expand eligibility rather than put the entirety of their Medicaid funding at risk, ${ }^{276}$ Vermont officials anticipated that $70 \%-100 \%$ of

272 N.Y. State Conference of Blue Cross \& Blue Shield Plans v. Travelers Ins. Co, 514 U.S. 645 (1995).

273 Id. at 659 .

${ }^{274}$ Id. at $659-60$.

$275 \mathrm{Id}$. at 664 .

276 See Nat'1 Fed'n of Indep. Bus. v. Sebelius, 567 U.S. 519, 519-20 (2012). 
residents currently enrolled in small-group employer-based coverage would transition to the single-payer plan. ${ }^{277}$

The ERISA statute does not allow for administrative waivers-the exemption Hawaii negotiated was written into the original statute. ${ }^{278}$ If the federal courts rule that a payroll tax to finance single-payer health care is preempted, states will have to identify other financing mechanisms or petition Congress to amend the statute. ${ }^{279}$

\section{Managing Federal Tax Implications}

A sharp increase in state payroll and income tax to finance a single-payer plan would also need to be assessed in terms of federal tax implications for residents and businesses. Although the amount of the state taxes could be calibrated to ensure that, on average, households and businesses would not pay any more for health coverage than they do under the status quo, the tax treatment of taxes paid to the state could differ from the tax treatment of privately purchased health benefits.

Under the 2017 federal tax reform law, state and local taxes (SALT) are only deductible up to a statutory cap. ${ }^{280}$ Commentators have noted that this approach punishes residents whose state and local governments take a progressive approach to taxing and spending on education, health care and other social safety net programs. ${ }^{281}$ The SALT cap does not apply to business expense deductions, however. ${ }^{282}$ Nor does it apply to the deductions individuals use to avoid taxation of health care expenditures. ${ }^{283}$

A report prepared for Oregon lawmakers by the RAND corporation determined that "employer-paid payroll taxes would, like employer Federal Insurance Contributions Act (FICA) contributions, be excluded from employees' taxable income, which would roughly preserve the current tax advantage. ${ }^{284}$ Similarly, a financing report assessing the Vermont single-payer plan noted that, "[b]ased on analysis of applicable federal law and discussions

277 See GMC 2014 REPORT, supra note 220, at 11-12.

27829 U.S.C. $\S 1144($ b)(5)(A).

${ }^{279}$ Such an amendment would face staunch opposition. See Bagley, supra note 118, at 12 ("[B]ecause of the intensity of the business lobby's resistance to limiting ERISA's preemptive scope, Congress is very unlikely to amend the law to address [state flexibility to pursue health reform]." (footnote omitted)).

280 See Alan Rappeport \& Jim Tankersley, I.R.S. Warns States Not to Circumvent State and Local Tax Cap, N.Y. TIMES (May 23, 2018), https://www.nytimes.com/2018/05/23/ us/politics/irs-state-and-local-tax-deductions.html [on file with Ohio State Law Journal]. For an explanation of the SALT deduction, see How Does the Deduction for State and Local Taxes Work?, TAX POL'Y CTR (2016), https://www.taxpolicycenter.org/briefing-book/howdoes-deduction-state-and-local-taxes-work [https://perma.cc/NF6S-P2MC].

281 See Rappeport \& Tankersley, supra note 280.

282 Tax Cuts and Jobs Act, Pub. L. No: 115-97 (2017).

283 Id.

${ }^{284}$ WHITE ET AL., supra note 92, at xiv. 
with United States Treasury, the public premium would be deductible for federal purposes on Schedule A as an income tax." 285 Individual payments would have to be carefully structured (as premiums, rather than income taxes) to avoid coming under the new cap on SALT deductions.

\section{Navigating Federal Constitutional Constraints}

Constitutional constraints would shape eligibility criteria for state-level single payer plans. Under Supreme Court precedent, the state would probably be required to open up eligibility to all current residents, regardless of the duration of residency. Some lawmakers might prefer to impose durational residency requirements to prevent an influx of new residents seeking immediate health care coverage. Although the attraction of workers and businesses to the state could be one of the benefits of adopting a single-payer plan, some may fear that immediate eligibility could attract a disproportionate number of people who need expensive care. Under Shapiro v. Thompson, however, the U.S. Supreme Court held that durational residency requirements for state welfare benefits violated the Fourteenth Amendment. ${ }^{286}$ Pointing to the fundamental right to travel, the Court held that "the purpose of inhibiting migration by needy persons into the State is constitutionally impermissible."287

Vermont legislators considered a durational residency requirement, 288 but ultimately Vermont's Act 48 tied eligibility to current residency, with resident defined as "an individual domiciled in Vermont as evidenced by an intent to maintain a principal dwelling place in Vermont indefinitely and to return to Vermont if temporarily absent, coupled with an act or acts consistent with that intent." 289

Were a state to adopt a single-payer health care plan, it would almost certainly be challenged on other constitutional grounds, even if the state eschewed durational residency requirements. Proponents of the fragmentary but universal strategy embodied in the ACA were overly confident in their assessments that the legislation would survive a constitutional challenge intact. Proponents of single-payer plans - especially at the state level — should not make the same mistake.

At either the federal or state level, business groups and individuals who oppose government-sponsored health coverage could argue that the taxes required to finance single-payer health care, the effect of government-sponsored competition on private insurers, and the near-monopoly a government payer would enjoy when it negotiates reimbursement rates with hospitals, physicians, pharmaceutical companies, and other providers violate individual rights to

285 See GMC 2014 REPORT, supra note 220, at 43.

${ }^{286}$ Shapiro, Comm'r of Welfare of Conn. V. Thompson, 394 U.S. 618 (1969).

287 Id. at 629.

288 See GMC 2014 REPORT, supra note 220, at 12.

${ }^{289}$ Act 48, 2011 V.T. H.202 § 2(a)(1) (2011), http://www.leg.state.vt.us/docs/2012/Acts /ACT048.pdf [https://perma.cc/5ET5-X9HW]. 
economic liberty. Notably, the ACA's individual mandate was challenged on structural grounds, not based on any claim to individual liberty. The popular conception that the government lacks authority to mandate personal choices about health insurance has been flatly rejected by the federal courts since the Supreme Court discredited Lochner v. New York. ${ }^{290}$

Particularly as the composition of the Court changes with the addition of Trump-Administration appointees, some commentators have suggested that a return to Lochner-era constitutional protections for economic liberty is more possible than it has been since the New Deal. ${ }^{291}$ A challenge to single-payer health care on the grounds that it impermissibly interferes with individual rights could be exactly the opportunity hard-line economic conservative judges need to reinstate economic due process.

\section{Assessing State Options From a HeAlth Justice PERSPECTIVE}

Maximizing Medicaid expansion under existing federal law should be an easy call for progressive states. Moreover, it is an essential component of the other two strategies described above. Beyond that, the question of what states should do is more complex. Assuming a strongly progressive state where voters express a preference for collectively financed universal health care coverage, the right path to achieving that is not entirely clear. The entrenchment of special interests as a political obstacle will vary from state to state. The fragmentary approach, which preserves a central and financially profitable role for private insurers and minimizes government influence on the health care prices charged by providers, ${ }^{292}$ could be more politically viable than the alternatives. But voters in progressive states are increasingly demanding more radical reforms that eschew public subsidization of private profits. ${ }^{293}$ From a legal standpoint, the public-option and the single-payer strategies are both likely to trigger legal challenges. There is a possibility that state legislators could carefully design a public option that is legally defensible in the absence of federal administrative

${ }^{290}$ Lochner v. New York, 198 U.S. 45 (1905) (holding 5-4 that a limitation on the hours that bakers could work violated the freedom of contract), abrogated by W. Coast Hotel Co. v. Parrish, 300 U.S. 379 (1937).

${ }^{291}$ Mark J. Stern, A New Lochner Era, SLATE (June 29, 2018), https://slate.com/newsand-politics/2018/06/the-lochner-era-is-set-for-a-comeback-at-the-supreme-court.html [https://perma.cc/S4EL-9Y9L].

292 Gluck \& Huberfeld, supra note 46.

293 John Sides, How the United States Built a Welfare State for the Wealthy, WASH. POST (Feb. 12, 2016), https://www.washingtonpost.com/news/monkey-cage/wp/2016/02/12/howthe-united-states-built-a-welfare-state-for-the-wealthy/ [https://perma.cc/5F6V-VZGT] ("Most citizens, even educated ones, do not understand who primarily benefits from tax subsidies. The complexity of tax expenditures makes it easier to distribute federal money to unpopular groups such as the wealthy and corporations. And middle-class voters who use these programs (although to a smaller degree) don't want to give up these benefits, even if in the abstract they want the government to reduce inequality."). 
approval. But threading that needle would almost certainly require a court judgment in the state's favor. Is it worth it for states to beg this kind of trouble? What benefits are on the table?

How should progressive health law scholars and advocates approach the question of whether states should take up the mantle of the ACA, supplementing it with a public option, or pursue the more radical strategy of single-payer? For me, the answer is that these options should be assessed from the perspective of health justice.

In recent years, a growing number of progressive health law scholars and advocates have begun using the term health justice to describe their goals. ${ }^{294}$ The term certainly has different meanings depending on who is using it. My own concept of health justice, developed in previous articles, ${ }^{295}$ is grounded in the work of the environmental justice, reproductive justice, and food justice movements, each of which has made eliminating health disparities a central goal. Drawing on the experiences of other social movements, and on the writings of political philosophers and ethicists on health justice, I have argued that health justice demands three commitments for the use of law to eliminate health disparities. First, to a broader inquiry that views access to health care as one among many social determinants of health deserving of public attention and resources. ${ }^{296}$ Second, to a more probing inquiry into the effects of class, racial, and other forms of social and cultural bias on the design and implementation of measures to reduce health disparities. ${ }^{297}$ And third, to collective action grounded in community engagement and participatory parity. ${ }^{298}$

From the perspective of other competing frameworks for health law scholarship, single-payer health care at any level of government would be anathema. The three main alternatives to health justice are the professional autonomy framework, the market justice framework, and the patient rights framework. ${ }^{299}$ The professional autonomy framework counsels that lawmakers and judges should support the autonomy of physicians, vis-à-vis corporate interests and the state. Single-payer health care would consolidate the purchasing power of the state at the expense of health care providers. The market power framework seeks to empower private commercial interests to foster competition among health care providers to offer higher quality, lower cost care

294 John COGgOn, What MaKes Health Public? A CRitical EVAluation OF MORAL, Legal, and Political Claims in Public Health 164-93 (2012).

295 See Lindsay F. Wiley, Health Law as Social Justice, 24 CORNELl J.L. \& PUB. POL'Y 47, 52 (2014) [hereinafter Wiley, Social Justice]; LaWrence O. Gostin \& LindSay F. Wiley, Public Health LaW: Power, Duty, Restraint 531-50 (3d ed. 2016); Wiley, Patient Rights, supra note 29, at 834-40.

296 Wiley, Social Justice, supra note 295, at 87-95.

297 Id. at $95-101$.

${ }^{298}$ Id. at $101-04$.

${ }^{299}$ See generally Wiley, Patient Rights, supra note 29 (describing alternative health law frameworks). 
while giving patients sufficient skin in the game to avoid unnecessary care. ${ }^{300}$ Single-payer health care - to varying degrees depending on the extent to which it is administered by private contractors - saps the market of any power it may have had to solve our health care woes. Even from the patient-rights perspective that has historically been the bastion of progressive health law scholarship and advocacy, single-payer health care is controversial. Putting individual patients at the center of health law and policy assessments begs the question: which patients? Those who currently have private employer-based coverage and the means to cover their out-of-pocket costs with minimal impact on their standard of living - a group that gets smaller every year? ${ }^{301}$ The quality of their coverage and the autonomy they exercise to choose providers and health plans could be diminished under a single-payer plan. But what about those who currently lack coverage? Those whose coverage provides insufficient financial protection? Those who are faced with difficult choices on a regular basis, such as whether to fill a prescription or buy groceries for the week?

From a health justice perspective that prioritizes elimination of social disparities in health, particularly through action on social determinants, the choice is clear. A single-payer system would overcome the stigma and political vulnerability that plagues Medicaid and improve health outcomes at the population level. ${ }^{302}$ State-level single-payer, in particular, would be more likely to reduce health care costs, freeing up funds to address other, more important determinants of health. ${ }^{303}$ Compared to federal single-payer, state-level singlepayer would also facilitate better integration of health care goals with those of public health regulation and social safety net programs, which operate primarily at the state and local level. ${ }^{304}$

\section{A. Combatting Stigma and Reducing Political Vulnerability}

In the United States, where the ethic of individualism teaches that "economic success is the reward of individual virtue, while economic failure (poverty) is an individual's own fault and reveals defect of character and lack of virtue," recipients of social welfare benefits have long been stereotyped as "lazy, immoral, and irresponsible." 305 The fragmentary system of public insurance and subsidized private insurance relies on and reifies a "perceived divide between good citizens with private insurance and socially undesirable

300 See, e.g., Roger M. Battistella, Health Care Turning Point: Why Single PAYER WON'T WORK 44 (2010) (“Improvements occur faster and with less acrimony when left to market competition than if the same objectives are sought through legislative edict or planning regulations when dealing with obstinate interest group opposition.”).

301 WHITE ET AL., supra note 92, at xiv-xv.

302 See Huberfield \& Roberts, supra note 14, at 8,9-16 (discussing the stigma associated with those receiving public benefits).

${ }^{303}$ See infra Part IV.C.

${ }^{304}$ See infra Part IV.B.

305 Joe R. Feagin, America's Welfare Stereotypes, 52 Soc. SCI. Q. 921, 931 (1972). 
dependents with public benefits." 306 The internalized stigma of Medicaid dependence plays an important role in deterring eligible people from enrolling, ${ }^{307}$ and the experience of stigma during encounters with health care providers discourages enrollees from seeking care. ${ }^{308}$ Social stigma also contributes to the program's political vulnerability and low reimbursement rates for providers, which, in turn, reinforce the stigma of Medicaid by signaling to providers that Medicaid enrollees are less deserving of attention than privately insured patients. 309

How we finance health care is tied to "how Americans ... think about what ties them together and to whom they have ties." 310 Single-payer reform would position health care as a collective, rather than individual, responsibility. ${ }^{311}$ The universality of a single-payer system would reflect a belief in the dignity and worth of all residents and the notion that our shared vulnerability to illness and injury warrants an obligation to provide mutual aid. ${ }^{312}$

\section{B. Improving Health Outcomes}

If the ultimate purpose of a health care system is to improve health outcomes, single-payer financing has many advantages. Relative to a federal single-payer plan, a system of state single-payer plans offers additional advantages. In particular, a state-level approach offers greater opportunities to harmonize the goals of the health care system with those of the public health system, public health regulations, and other social welfare programs that influence the social determinants of health.

Studies of the impact of Medicaid coverage on health outcomes demonstrate modest improvements by most criteria. ${ }^{313}$ These findings are unsurprising to anyone familiar with the reams of evidence demonstrating that social factors

${ }^{306}$ Huberfield \& Roberts, supra note 14 , at 8; see also Maher, supra note 106, at 143 (arguing the U.S. health system's reliance on employer-based coverage "perpetuate[s] mistaken beliefs about who deserves health insurance (and thus health care)").

${ }^{307}$ See Jennifer Stuber \& Karl Kronebusch, Stigma and Other Determinants of Participation in TANF and Medicaid, 23 J. POL'Y ANALYsis \& MGMT. 09, 526 (2004).

308 See Heidi Allen et al., The Role of Stigma in Access to Health Care for the Poor, 92

(2) MilBanK Q. 289, 301-04 (2014) (describing an instance where a newly insured individual felt judged for being previously uninsured, and therefore did not follow up with her new physician).

309 See Huberfeld \& Roberts, supra note 14, at 12-13.

310 Deborah A. Stone, The Struggle for the Soul of Health Insurance, 18 J. HEALTH POL. POL'Y \& L. 287, 289 (1993).

311 See Laura Katz Olson, The Politics of Medicaid 240 (2010).

312 See Stone, supra note 310, at 290-91.

313 See Julia Paradise \& Rachel Garfield, What Is Medicaid's Impact on Access to Care, Health Outcomes, and Quality of Care? Setting the Record Straight on the Evidence, KAISER FAM. Found. (Aug. 2, 2013), https://www.kff.org/medicaid/issue-brief/what-is-medicaidsimpact-on-access-to-care-health-outcomes-and-quality-of-care-setting-the-record-straighton-the-evidence/view/print/ [https://perma.cc/N7VJ-MVNP]. 
other than access to health care - such as safe, healthy, and affordable housing, safe drinking water, access to nutritious food, and other social support systems - play a far greater role in determining health outcomes. ${ }^{314}$ Yet, for various reasons - including the greater susceptibility of health care spending to be captured by politically powerful interests and the fact that the lives public health and social spending saves are rarely identifiable-public health and social safety net spending are dwarfed by spending on medical care. ${ }^{315}$

Through various mechanisms, public health advocates and policymakers interested in cost-savings are attempting to hold health care providers financially responsible for the health outcomes of the populations they serve. Value-based payment ties reimbursement rates to outcomes and new strings attached to hospitals' tax-exempt status require them to assess community health needs and take steps to address them. ${ }^{316}$ These efforts have supported a longstanding reorientation of clinicians toward preventive medicine. ${ }^{317}$ But health care providers have not yet adopted the population perspective of public health, probably because fragmentary health care financing means their incentives are not well aligned with long-term population health goals. ${ }^{318}$ The health care system is driven by the needs of paying patients over the period of an annual budget, while public health must serve the needs of the entire community-especially its most vulnerable members-over the full lifecourse. ${ }^{319}$ Chances are slim that the insurance company that decides how much a pediatrician is paid to talk with a vaccine-hesitant parent about her concerns will be the same company responsible for the costs of treating an infant who is infected by the unvaccinated child of the hesitant parent. There is virtually no chance that the insurance company that determines how much a health care provider is paid to treat a 14-year-old boy's nicotine dependence will be responsible for his health care costs if he develops cancer forty years later. Moreover, there is a limit to the political influence of health insurance companies and employers over more powerful tools such as school vaccination laws, tobacco taxes, advertising restrictions, and disclosure requirements.

314 Gostin \& WILEY, supra note 295, at 533-34.

315 See id. at 443, 542 (discussing the role of politically powerful interests and the unidentifiable lives problem in public health); Frakt, supra note 3 (discussing low U.S. spending on social programs excluding health care relative to other similarly wealthy countries); David U. Himmelstein \& Steffie Woolhandler, Public Health's Falling Share of US Health Spending, 106 AM. J. Pub. Health 56, 56 (2016) (finding that "public health's share of total health expenditures rose from $1.36 \%$ in 1960 to $3.18 \%$ in 2002 " when spending briefly surged in the wake of the $9 / 11$ attacks, "then fell to $2.65 \%$ in 2014 ," a decline of $17 \%)$.

316 See Lindsay F. Wiley, The Struggle for the Soul of Public Health, 41 J. HEALTH POL. POL'Y \& L. 1083, 1084 (2016).

317 See id.

318 See id. at 1083-87 (discussing how health care providers are approaching prevention by looking at outdated models focusing on influencing individuals to change their behaviors).

${ }^{319}$ See Wiley, Patient Rights, supra note 29, at 852. 
By eliminating (or dramatically reducing) fragmentation in health care financing, single-payer health care could better align incentives between the health care and public health systems. Vermont lawmakers identified "[s]hifting the focus of care from intervention to prevention and wellness" as an explicit goal of their proposal. ${ }^{320}$ But the potential to promote prevention and wellbeing extends beyond the health care setting. Under a single-payer system, there would be near-total overlap between the primary payer for health care goods and services (taxpayers) and those who exercise control over the most crucial social determinants of health (voters). ${ }^{321}$

Federal single-payer health care could prompt further federalization of other social safety net programs and public health law. The linkage between growing federal subsidization of health care and federalization of interventions to address the social determinants of health is readily apparent. For example, the ACA included calorie labeling requirements for chain restaurants and artificial tanning taxes, as well as a significant infusion of funds for community prevention. ${ }^{322}$ Federalization may pull more progressive jurisdictions back toward a national mean. Preemption of state and local menu labeling laws by federal requirements weakened requirements in some jurisdictions, for example. ${ }^{323}$ Federalization also tends to align public health priorities more closely with national security priorities, a linkage that prompts wariness among most public health advocates. ${ }^{324}$

State and local governments exercise primary responsibility for public health. ${ }^{325}$ They also exercise primary authority over most of the social net programs that shape the social determinants of health. ${ }^{326}$ State-level singlepayer health care would allow for better harmonization of health care and public health goals, giving state taxpayers and voters greater control over both.

\section{Lowering Health Care Costs}

Excessive spending on health care relative to public health and other social services is one of the factors that distinguishes the U.S. from other similarly situated countries. ${ }^{327}$ Because health status is largely determined by factors

320 HSIAO ET AL., supra note 8 , at 3.

321 See id. at 3-6 (using health care reform in Vermont as an example).

322 Gwendolyn Roberts Majette, PPACA and Public Health: Creating a Framework to Focus on Prevention and Wellness and Improve the Public's Health, 39 J.L. MED. \& ETHICS 366, 373-75 (2011).

323 See James G. Hodge, Jr. et al., Public Health Preemption: Constitutional Affronts to Public Health Innovations, 80 OHIO ST. L.J. 685 (2018).

324 See Nan D. Hunter, "Public-Private” Health Law: Multiple Directions in Public Health, 10 J. HeAlth CARE L. \& POL'y 89, 90 (2007); Lindsay F. Wiley, Adaptation to the Health Consequences of Climate Change as a Potential Influence on Public Health Law and Policy: From Preparedness to Resilience, 15 WIDENER L. REV. 483, 505 (2010).

325 GOSTIN \& WILEY, supra note 295, at 87.

326 Id. at 283

327 See Sawyer \& Cox, supra note 1. 
other than access to health care, improving health outcomes requires controlling health care costs. ${ }^{328}$

Beyond increasing access to health care for all residents, one of the primary benefits of a single payer system is negotiating power to lower costs while maintaining participation by providers. Single-payer systems have significantly lower administrative costs (encompassing all of the operating costs of the health care system other than payments to providers for clinical services). ${ }^{329}$ Overhead costs are lower for health care providers (who save the time they otherwise spend navigating the requirements of multiple payers) and profits for payers are eliminated, at least to the extent that lawmakers eschew reliance on private, forprofit contractors. ${ }^{330}$ Payments to providers for clinical services are also lower under a single-payer plan than the public option ${ }^{331}$ or fragmentary but universal strategy. ${ }^{332}$ Health care economists generally assume that shifting to a singlepayer system would increase patient demand for services. On the other hand, the impact of increased demand for services would likely be offset by the superior negotiating position of a single payer, leading to a reduction in the price of services ${ }^{333}$ in addition to lower administrative costs. ${ }^{334}$

A single-payer system built on Medicaid could look quite different from a system built on Medicare. Medicare's reimbursement rates fall in between those adopted by private insurers and those adopted by state Medicaid plans. ${ }^{335}$ Medicare's network of participating providers is superior to that enjoyed by the average private insurance enrollee, which in turn is better than the network of providers willing to accept the average Medicaid plan. ${ }^{336}$ On the other hand, Medicaid's actuarial value - the financial protection from out of pocket costs that it affords to enrollees - is considerably higher than that of private insurance or Medicare. ${ }^{337}$ Indeed, traditional Medicare's actuarial value is so low that

328 See Frakt, supra note 3.

${ }^{329}$ See WhITE ET AL., supra note 92, at xiv-xv, 11.

${ }^{330}$ See id. at 11 .

331 See id. at xi (assuming for the purposes of analysis that under Oregon's public option proposal, provider rates would match Medicare fee-for-services rates).

332 See id. at $\mathrm{x}$ (projecting that under the "Obamacare-for-All" plan under which state and federal funds would be pooled to subsidize private health insurance for all state residents, provider rates would be "slightly below the rates paid by commercial plans in the Status Quo but are higher on average than under the Status Quo")

${ }^{333}$ See, e.g., id. at $\mathrm{x}$ (assuming that Oregon's purchasing power as nearly-single payer would result in a $10 \%$ reduction in the price of clinical services).

$334 \mathrm{Id}$. at xiv-xv.

335 See MANATt HEALTH, supra note 92, at 3.

${ }^{336}$ See Gretchen JACOBSON ET AL., KAISER FAM. Foundation, MEdicARE Advantage: How Robust Are Plans' Physician Networks? 4 (2017).

337 See Sophie Beutel et al., Realizing Health Reforms: How Much Financial Protection Do Marketplace Plans Provide in States Not Expanding Medicaid?, COMMONWEALTH Fund (June 2016), https://www.commonwealthfund.org/sites/default/files/documents/media files_publications_issue_brief_2016_jun_1881_beutel_financial_protection_marketplace_p lans_rb_v2.pdf [https://perma.cc/BQ3Y-6CWR] 
almost all enrollees purchase supplemental insurance or receive it via Medicaid or as an employment or retirement benefit. ${ }^{338}$

As a platform for establishing a single-payer plan, Medicaid could be in a better position to save costs through lower reimbursement rates. Medicare reimbursement rates are established at the federal level, via complex formulas that take geographic variations in overhead and labor costs into account. ${ }^{339}$ Traditional Medicaid reimbursement rate formulas are determined by each state pursuant to federal guidelines and approved by CMS. ${ }^{340}$ As discussed above, however, the majority of Medicaid enrollees are now covered by private Medicaid managed care plans, which establish their own reimbursement rates. ${ }^{341}$ On average, however, Medicaid pays prices that are about two-thirds of what Medicare pays. ${ }^{342}$

A state developing a single-payer system will face massive political pressure to adopt reimbursement rate formulas that are considerably more generous than current Medicaid rates. ${ }^{343}$ Vermont officials, for example, assumed that initially, uniform reimbursement rates paid by the single-payer system would rely on Medicare's formulas (fee-for-service for most physician care and prospective payment based on diagnosis-related groups for hospital care), but keyed to a higher baseline payment than Medicare uses. ${ }^{344}$ Over time, however, they envisioned the state-run system transitioning away from fee-forservice and prospective payment toward risk-adjusted capitation payments that shift some financial risk to providers and reward them for better outcomes. ${ }^{345}$

Would the network adequacy problems - and resulting barriers to accessing care-experienced by people currently covered by Medicaid continue if Medicaid absorbs a larger share of the population, including those who are relatively healthier and better off financially? Would universal access to Medicaid change the political calculus and lead to higher reimbursement rates? Politics drive reimbursement rates for publicly administered coverage. And reimbursement rates plus the payer's market share drive network adequacy.

338 See generally Lipschutz et al., supra note 200 (discussing consumer protections but in place for those enrolled in Medicare, which highlights the limited coverage of Medicare in some areas).

339 See Medicaid and ChIP Payment And AcCess (MACPAC), Medicaid Physician Payment Policy 2 (Apr. 2016), https://www.macpac.gov/wp-content/uploads/2016/04/

Medicaid-Physician-Payment-Policy.pdf [https://perma.cc/2PU7-56XD] [hereinafter MACPAC].

340 See id. at 3.

341 See supra Part I.B.

342 See MACPAC, supra note 339, at 3-4.

${ }^{343}$ See HSIAO ET AL., supra note 8, at 7 (reporting economic analysis predicting that "[a]ny measurable reduction to the total amount paid to hospitals could jeopardize the survival of Vermont hospitals" and "stakeholder analysis [indicating] that hospitals would mobilize all their political strength and support to oppose any reduction in the total amount paid to hospitals").

${ }^{344}$ See id. at $\mathrm{x}$.

${ }^{345} \mathrm{Id}$. 
Of course, it is entirely possible that a U.S. single-payer system — at the state or federal level-would ultimately bear little resemblance to the limitedeligibility program touted as its platform. ${ }^{346}$ Medicare for All has gained traction, but it is unclear whether a federal single-payer plan could —or shouldbear much resemblance to Medicare. ${ }^{347}$ Some state legislators have even taken to referring to their state-level single payer plans as Medicare for All. ${ }^{348}$

\section{Proceeding with a Cautious Eye Toward the Disadvantages of State- Level Single-Payer Health Care}

Although there are many potential advantages of transitioning to a singlepayer plan at the state level, lawmakers must exercise caution in undertaking such a momentous shift. Critics of single-payer health care warn that it could reduce access to care even as access to coverage becomes universal. ${ }^{349}$ In addition, pioneering single-payer at the state level could exacerbate geographic disparities in health between states with universal coverage and those without. ${ }^{350}$ In addition, state-level single payer would result in a system where protections for the state's residents under federal law continued to be fragmented, depending on the resident's status under Medicare, Medicaid, and the ACA. ${ }^{351}$ Finally, depending on how the state proceeds, state-level singlepayer could also put the vulnerable populations currently covered by Medicaid at risk by moving the program closer to private insurance or Medicare and further from the special coverage Medicaid was designed to provide for special populations.

\section{Exacerbating Nonfinancial Barriers to Care}

Reducing provider reimbursement rates would eventually lead to a reduction in the supply of physicians, hospital care, and other services that currently command prices far higher than those seen in other wealthy countries. ${ }^{352}$ For example, an analysis of Oregon's single-payer proposal by the RAND Corporation assumed that a $10 \%$ reduction in the price of clinical services (achieved through the state's enhanced negotiating power) would lead

346 See Ed Kilgore, Medicare for All Won't Bring Medicare to All, N.Y. MAG. (July 13, 2018), http://nymag.com/daily/intelligencer/2018/07/medicare-for-all-wont-bring-medicare -to-all.html [https://perma.cc/W7R5-GTZL].

347 Id.

348 See e.g., Press Release, Carl E. Heastie, Speaker, N.Y. State Assemb., Assembly Passes New York Health Act (June 14, 2018), http://nyassembly.gov/Press/files/201806 14.php [https://perma.cc/FP89-ZL3Q] (quoting the sponsors of the single-payer bill approved by the New York Assembly referring to the plan as "Medicare for All").

349 See infra Part IV.D.1.

350 See infra Part IV.D.2.

${ }^{351}$ See infra Part IV.D.3.

352 See WHITE ET AL., supra note 92, at xiv; Sawyer \& Cox, supra note 1. 
to a reduction in the volume of services supplied. ${ }^{353}$ A reduction in supply would, in turn, result in nonfinancial barriers to care, such as longer wait times or the need for patients to travel longer distances to access care. ${ }^{354}$ Longer wait times and the need to travel longer distances could discourage residents from seeking needed care. ${ }^{355}$ A state's increased negotiating power may result in more providers participating in a state-level single-payer or public-option plan's network than currently participate in the state's Medicaid plan. ${ }^{356}$ But if there are fewer health care providers in the state overall (because they move to other jurisdictions where reimbursement rates are higher or because fewer residents decide to become physicians or operate health care businesses), access to care could suffer.

\section{Exacerbating Geographic Disparities in Health}

In 2013, prior to implementation of the ACA's Medicaid expansion, there was a nearly "six-fold difference" between the state with the lowest uninsured rate (Massachusetts) and the state with the highest (Texas). ${ }^{357}$ In the aftermath of the U.S. Supreme Court's decision in NFIB v. Sebelius rendering the expansion optional, the coverage gap from state to state has widened. ${ }^{358}$ If pioneering states are able to achieve universal coverage through a public-option or single-payer plan, the gap would widen even more.

Health outcomes are heavily determined by geography. ${ }^{359}$ Social epidemiologists have documented the many ways in which the places where a person works, lives, and attends school shape her likelihood of living a long and healthy life. ${ }^{360}$ Most of this variation is probably due to social determinants that extend well beyond access to health care. But some of it may be attributable to policies that dictate access to insurance coverage. Single-payer and publicoption waivers could ultimately result in wealthier states (with more progressive politics) doing more to provide access to coverage for their own residents, while

353 White et al., supra note 92, at xiii-xiv.

$354 \mathrm{Id}$. at xiv.

355 See Ronald M. Andersen, Revisiting the Behavioral Model and Access to Medical Care: Does It Matter?, 36 J. Health \& Soc. BehaV. 1, 3 (1995)

356 Oregon officials are considering an approach that "would require providers who participate in other state health programs (including the Oregon Health Plan and any plans offered to public employees) also to participate in the Public Option." WHITE ET AL., supra note 92 , at xi.

357 David C. Radley et AL., COMmonwealth Fund, Aiming Higher: Results From the Commonwealth Fund Scorecard on State Health System Performance 13 (Mar. 2017), http://www.commonwealthfund.org/ /media/files/publications/fund-report /2017/mar/1933_radley_aiming_higher_2017_state_scorecard_final_v3_03_15_2017.pdf. [https://perma.cc/8GMA-FNMT] ("23\% in Texas vs. $4 \%$ in Massachusetts").

358 Id. at 10.

359 Gostin \& WILEY, supra note 295 , at 534.

${ }^{360} \mathrm{Id}$. 
their interest in protecting Medicaid programs in poorer, more conservative states wanes.

\section{Continuing Fragmentary Federal Protections for State-Level Single- Payer Enrollees}

Even if nearly all state residents are covered by the same payer, the rights of state single-payer enrollees under federal law would still be fragmentary, depending on their eligibility for various federal programs. ${ }^{361}$ As discussed above, enrollees who fall within traditional Medicaid eligibility categories would be entitled to the full protections of Section 1902 of the SSA. ${ }^{362}$ Depending on the contours of the state's 1332 waiver, those for whom the state receives ACA premium assistance tax credits could be entitled to receive Essential Health Benefits. ${ }^{363}$ Others-particularly those from middle- and higher-income families who were covered by employer-based plans prior to opting into the state's single-payer plan, would receive very little protection under federal law. ${ }^{364}$

\section{Putting Federal Protections for the Highest-Need Populations at Risk}

The ACA's reliance on Medicaid as one piece of a universal coverage pie is controversial among some Medicaid advocates. Historically, expansions in eligibility to adults without disabilities and those living in higher-income households has been accompanied by increased privatization, managed care, and cost-sharing. ${ }^{365}$ These changes have diminished Medicaid's traditional focus on providing special coverage for special populations, while still preserving core protections for enrollees. ${ }^{366} \mathrm{~A}$ shift toward relying even more heavily on Medicaid as a platform for buy-ins by higher income residents or for a single-payer plan would raise similar concerns. ${ }^{367}$ Would negotiations within the state (between lawmakers and private insurers, health care providers, and other stakeholders) and between the state and the federal government (where the same stakeholders could put pressure on the administration to protect their interests) result in a greater role for privatization, managed care, and cost sharing? What about in conservative states where a public option might be explored as an alternative to expanding Medicaid under the ACA, a move that

${ }^{361}$ Cf. Sidney D. Watson, Out of the Black Box and into the Light, Using Section 1115 Medicaid Waivers to Implement the Affordable Care Act's Medicaid Expansion, 15 YALE J. HEALTH POL'Y L. \& ETHICS 213, 219-20 (2015) (describing a specific example of fragmentary application of benefits depending on federal program eligibility).

362 See supra Part II.B.

363 See MANATT HeALTH, supra note 92, at 4.

364 See supra Part III.A.2.

365 Watson, supra note 361 , at 219.

366 See id. at $220-21$.

${ }^{367}$ See Lav \& Hernández-Delgado, supra note 189, at 3. 
Medicaid advocates have opposed? ${ }^{368}$ Vermont officials considered a singlepayer option that would have been entirely administered by public employees, but a state-commissioned report led by Dr. William C. Hsiao recommended an alternative that would have "preserve[d] a small space for private insurance firms by contracting out, through a competitive bid process, the claims administration and provider relations functions of the single payer."369 This public-private partnership, Hsiao and his coauthors suggested, would be the "most feasible [option] as it is likely to be accepted by the broadest cross-section of Vermont stakeholders." 370 The other states have not yet gotten far enough for us to know whether their Medicaid for All plan would have in fact been a private managed care organization (or dozens of them), a publicly-run plan, or some combination of the two. Similarly, the roles of cost-sharing and managed care practices (such as utilization review and risk-sharing with providers) have not yet been addressed in full by any of the states examining single-payer or publicoption proposals. Lawmakers and administrative officials considering the role of these powerful tools must strike a delicate balance between deterring overutilization of high-cost, low-value goods and services and preventing underutilization of lower-cost, high-value care that could prevent greater expense and suffering down the road.

\section{CONCLUSION}

If single-payer health care is ever to become a reality in the United States, it will very likely be pioneered by a state government, much like Canada's single-payer system was first adopted in the provinces. ${ }^{371} \mathrm{~A}$ single-payer system entirely financed and administered by the U.S. federal government would be unprecedented in its scale. Canada's system operates more like U.S. Medicaidfinanced nationally but administered largely by the provinces - than U.S. Medicare. The U.S. Medicare program already covers more people than the largest single-payer system in the world..$^{372}$

368 See id.

${ }^{369}$ HSIAO ET AL., supra note 8 , at xii.

370 Id. at xviii.

371 Jacalyn Duffin, The Impact of Single-Payer Health Care on Physician Income in Canada, 1850-2005, 101 Am. J. Pub. Health 1198, 1199 (2011).

372 U.S. Medicare currently covers nearly 60 million enrollees. CMS Fast Facts, CMS.gOV (Aug. 1, 2018), https://www.cms.gov/Research-Statistics-Data-and-Systems/ Statistics-Trends-and-Reports/CMS-Fast-Facts/index.html [https://perma.cc/J953-PXRG]. Britons are covered by separate single-payer systems for England, Northern Ireland, Scotland, and Wales, administered by the Parliament of the United Kingdom, the Northern Ireland Assembly, the Scottish Government, and the Welsh Assembly Government, respectively. About the NHS, NHS (Apr. 13, 2016), https://www.nhs.uk/using-thenhs/about-the-nhs/the-nhs/ [https://perma.cc/6CJK-V86P]. The National Health Service in England covers 54.3 million enrollees. Id. As noted above, Canadians are covered by singlepayer systems jointly financed and administered by the federal and provincial governments, but even if there were a national single-payer system in Canada, the entire Canadian 
States seeking to pioneer single-payer health care face complex legal obstacles. Although it might be possible for a state to proceed without the acquiescence of the federal executive or the support of the federal Congress, it is probably not feasible. Thus, single-payer proponents may have to wait until an amenable president is elected in 2020 or beyond, or until Congress comes under the control of progressive Democrats - with the former being the more likely of the two scenarios. In the meantime, there are steps interested state lawmakers and executives can take to prepare. Maximizing Medicaid eligibility within existing federal law ensures affordable coverage for non-immigrant residents living in low-income households. It also increases the number of state residents whose coverage by a state-level single-payer plan could ultimately be subsidized by federal Medicaid funds. Strengthening the ACA exchanges supports subsidized private coverage to residents who are not eligible for Medicaid but lack access to employer-based care. It also sustains a platform for offering a public option to some or all residents, which could make coverage more affordable while bolstering the political will required for more radical reforms.

The health justice framework would provide a better grounding than alternative health law paradigms for the legal interventions that would be required to implement state-level single-payer health reform. To determine that state authority to levy a payroll tax to finance a single-payer plan is not preempted by ERISA, federal judges could rely on the longstanding authority

population is just over 35 million. Census Program, Stat. Canada (Oct. 4, 2018), https://www12.statcan.gc.ca/census-recensement/index-eng.cfm [https://perma.cc/PJH9H24E]. The populations of other countries with single-payer systems are far smaller: Taiwan (about 23.7 million) Sweden (about 10 million), Denmark (about 5.8 million), Norway (about 5.4 million), and New Zealand (about 4.7 million). Countries in the World by Population, WORLDOMETERS, http://www.worldometers.info/world-population/populationby-country/ [https://perma.cc/59L9-Y69A]. Only mainland China and India have larger total populations than the United States. Id. The New Rural Co-operative Medical Care System in mainland China subsidizes basic health care for about 802 million people living in rural areas (urban residents are not eligible), but it is jointly financed and administered by the central government and localities, with benefits and reimbursement varying across hundreds of local governments. Lidan Want et al., Who Benefited from the New Rural Cooperative Medical System in China? A Case Study on Anhui Province, BMC Health Servs. Res. 16 (2016), https://www.ncbi.nlm.nih.gov/pmc/articles/PMC4893416/ [https://perma.cc/7XR8TUA7]. In 2018, Indian Prime Minister Narendra Modi announced a plan to cover health care costs for people living in about 100 million low-income households up to an annual cap. Vidhi Doshi, India Just Announced a Vast New Health Insurance Program. But Can It Afford It?, WASH. POST (Feb. 1, 2018), https://www.washingtonpost.com/world/asia_pacific/indiajust-announced-a-vast-new-health-insurance-program-but-can-it-afford-it/2018/02/01/805 efb46-0757-11e8-ae28-e370b74ea9a7_story.html

[https://perma.cc/5UCL-5NN4]. "Modicare," as the plan is known, would also be jointly financed and administered by the central government, states, and union territories, which are given the option of relying on private insurance companies or public administration. Will 'Modicare' Be a Game Changer for India?, KNOWLEDGE AT WARTON (Oct. 8, 2018), http://knowledge.wharton.upenn.edu/ article/will-modicare-game-changer-india/ [https://perma.cc/4T59-N84K]. 
of states to protect the public's health, pursuant to police powers that have not been ceded to federal lawmakers. ${ }^{373}$ Courts cognizant of the health justice framework should be especially reluctant to infer that ERISA was intended to preempt a state's authority to tax and spend for the public's health. To approve 1115 and 1332 waivers for state-level single-payer health reform, an amenable administration would have to determine that the state's single-payer plan would promote the objectives of Medicaid and the ACA. Lawyers for the state and HHS could rely on the health justice framework to emphasize that Medicaid and the ACA were intended to promote population health and uniquely public interests, including interests in eliminating health disparities, apart from the individual rights of the programs' current beneficiaries. Health justice advocates, focused on integrating the health care and public health systems to eliminate disparities and improve population-level health outcomes, stand ready to assist with meaningful state-level reforms.

373 See Gostin \& WILEY, supra note 295, at 87-88; Janet L. Kaminski, ERISA Preemption and State Health Care Reform, CT Gen. ASSEMB. (Feb. 9, 2007), https://www.cga.ct.gov/2007/rpt/2007-R-0131.htm [https://perma.cc/S95G-J3VQ]; HSIAO ET AL., supra note 8, at 10. 
